\title{
Improving the representation of roots in terrestrial models
}

2 Erica A.H. Smithwick ${ }^{1}$, Melissa S. Lucash ${ }^{2}$, M. Luke McCormack ${ }^{3}$, and Gajan Sivandran ${ }^{4}$

$3{ }^{1}$ Department of Geography and Intercollege Graduate Program in Ecology, The Pennsylvania

4 State University, 302 Walker Building, University Park, Pennsylvania 16802, USA

$5 \quad{ }^{2}$ Department of Environmental Science and Management, Portland State University, B1-24A

6 Science Research and Teaching Center, Portland, OR 97201, USA

$7 \quad{ }^{3}$ Key Laboratory of Ecosystem Network Observation and Modeling, Synthesis Research Center

8 of Chinese Ecosystem Research Network, Institute of Geographic Sciences and Natural

9 Resources Research, Chinese Academy of Sciences, Beijing, 100101, China.

$10{ }^{4}$ Department of Civil, Environmental and Geodetic Engineering, Ohio State University

11 483B Hitchcock Hall, Columbus, OH 43210

15 Corresponding Author:

16 Erica A. H. Smithwick

17 Department of Geography

18302 Walker Building

19 University Park, Pennsylvania 16802, USA

20 Tel: 814-865-6693

21 Email: $\underline{\text { smithwick@psu.edu }}$

22 Fax: 814-863-7943

23 KEYWORDS: ROOTS, TURNOVER, CARBON, MODELING, ALLOCATION, PARAMETERIZATION
DRAFT: July 18, 2013; Revised May 17, 2014

Ecological Modelling, Research Review

Word Count: Abstract 232; Main text: 6887 
Abstract

Root biomass, root production and lifespan, and root-mycorrhizal interactions govern soil carbon fluxes and resource uptake and are critical components of terrestrial models. However,

27 limitations in data and confusions over terminology, together with a strong dependence on a

28 small set of conceptual frameworks, have limited the exploration of root function in terrestrial

29 models. We review the key root processes of interest to both field ecologists and modelers including root classification, production, turnover, biomass, resource uptake, and depth

31 distribution to ask (1) what are contemporary approaches for modeling roots in terrestrial

32 models? and (2) can these approaches be improved via recent advancements in field research

33 methods? We isolate several emerging themes that are ready for collaboration among field 34 scientists and modelers: (1) alternatives to size-class based root classifications based on function 35 and the inclusion of fungal symbioses, (2) dynamic root allocation and phenology as a function 36 of root environment, rather than leaf demand alone, (3) improved understanding of the treatment 37 of root turnover in models, including the role of root tissue chemistry on root lifespan, (4) better 38 estimates of root stocks across sites and species to parameterize or validate models, and (5) 39 dynamic interplay among rooting depth, resource availability and resource uptake. Greater 40 attention to model parameterization and structural representation of roots will lead to greater 41 appreciation for belowground processes in terrestrial models and improve estimates of ecosystem 42 resilience to global change drivers. 
INTRODUCTION

Forecasting the resilience of Earth's ecosystems to perturbation or stress induced by climate change increasingly requires an understanding of the influence of belowground processes

47 on ecosystem function. Roots couple the aboveground vegetation and the soil media, yet they are arguably the least understood portion of the ecosystem. As a result they are represented idealistically in many process-based ecosystem models, and remain the most simplistic component of contemporary Earth System Models (ESMs). Despite this, feedbacks between

\section{1} aboveground and belowground function are expected to influence ecosystem responses to changes in climate and atmospheric $\left[\mathrm{CO}_{2}\right]$. For example, models currently predict that rising $\left[\mathrm{CO}_{2}\right]$ and temperature may increase aboveground productivity (Millar et al., 2007; Mote et al.,

54 2003; Parmesan and Yohe, 2003), but productivity may be limited by soil nutrients and water availability (Albani et al., 2006; Boisvenue and Running, 2010; Jain et al., 2013; Luo et al., 2004; Norby et al., 2010). There is an urgent need for scientists to improve prognostic approaches for understanding how roots govern changes in resource availability and how root responses influence ecosystem productivity.

There are several common assumptions that have historically guided the treatment of root function in terrestrial models. One of the primary assumptions is that net primary productivity is

61 influenced by soil nutrient and water availability, with root investment increasing water and 62 nutrient uptake. These effects are often modeled indirectly through stoichiometric relationships 63 among limiting nutrients that govern productivity in above- and belowground pools and/or 64 demand-supply relationships rather than through direct representation of the physical processes 65 that control root uptake. Second, root biomass is often determined using allometric relationships 66 between above- and belowground pools, rather than determined independently. Third, carbon 
67 (C) flux from roots to soil or the atmosphere is dependent on root turnover and respiration rates, which are dependent on soil conditions. These turnover and respiration rates are often grouped by plant functional type, rather than species, and root respiration is lumped with microbial

70 respiration to calculate the total loss of $\mathrm{C}$ to the atmosphere.

These relatively simple algorithms belie a growing understanding of complex root dynamics emerging from empirical root ecology studies. Root order (Guo et al., 2008b), fungalroot associations (Smith and Read, 2008), and root-rhizosphere interactions such as priming (Zhu and Cheng, 2011) are viewed as critically important by empiricists, but these are not currently implemented in most models, with notable exceptions (Orwin et al., 2011; Parton et al., 2010). Moreover, root tissue chemistry and soil conditions dramatically affect root lifespan, but are not included in contemporary model approaches (Smithwick et al., 2013). There is an opportunity, therefore, to draw renewed attention to how roots are incorporated into model frameworks and encourage future collaborative efforts among empirical scientists and modelers. Heightened representation of root processes and feedbacks in ecosystem models may unravel relationships that heretofore were obfuscated by representation of roots as black boxes, and may elucidate the conditions that lead to ecosystem resilience or sensitivity under global change stressors.

Historically, incorporating root processes into models has been hampered by (1) a lack of consistent and scalable data on root properties that govern root structure (classification and arrangement) and function (processes that govern root production, turnover, and uptake), (2) differences in terminology between root ecologists and modelers, which have led to confusion even over relatively 'simple' terms like turnover (McCormack et al., in press), and (3) limited consensus on which root functions are ripe for inclusion in contemporary models. For example, understanding species-specific root function in mixed-species forests is hampered by empirical 
observations that are recorded at the stand-level and which do not distinguish among tree species. Similarly, where species-specific estimates exist, spatial and temporal heterogeneity among species is often ignored when summarizing processes at the level of Plant Functional Type (PFT). Yet it is known that species-specific differences in root turnover are important at continental scales and can significantly affect estimates of C storage (McCormack et al., 2013). challenges described above (scaling root data, issues of terminology, and assessment of modeling

97 opportunities). The review is organized around root concepts common to both empirical ecologists and modelers, including root classification schema, production, turnover, biomass, resource uptake, and depth distribution (Table 1). We present the empirical community with opportunities for future field studies by highlighting gaps in data and theory that hinder the incorporation of belowground feedbacks into models. Similarly, we conclude with recommendations for areas of model advancement that may improve forecasts of terrestrial 103 ecosystems to global change drivers based on contemporary understanding of root function.

\section{EMERGING OUTLOOKS IN ROOT STRUCTURE AND FUNCTION}

\section{Root Classification: Root size, function and mycorrhizal status}

All roots are not created equally in terms of growth and resource acquisition. Physical separation of roots into two size classes, fine $(<2 \mathrm{~mm}$ in diameter $)$ and coarse $(>2 \mathrm{~mm}$

109 diameter), has been the classic approach (Jackson et al., 1997) for correlating root function and 110 structure in both experimental and modeling approaches. In this classification, fine roots are 111 considered to be non-woody, ephemeral roots that absorb nutrients and water, whereas coarse 112 roots explore large volumes of soil and function primarily in anchorage, transport, and storage 
113 (Pregitzer, 2002). More recently, however, researchers have begun to question the utility of this 114 simple dichotomous separation, increasingly recognizing the complexity of root structure (Fig.

115 1) and the need to more precisely quantify the root properties associated with these classification 116 schemes. For example, within the fine root size class, distal tips of roots (first- and second-order 117 roots) are often thinner, more active in nutrient uptake, richer in nitrogen $(\mathrm{N})$ and have higher 118 respiration rates than basal roots (Pregitzer, 2002; Pregitzer et al., 1998). The majority of root 119 length and surface area is also concentrated in these first- and second-order roots, which provide 120 the high surface area needed for resource acquisition (Guo et al., 2004; Pregitzer, 2002). In a 121 comprehensive, cross-species study, branching order was a more accurate indication of root 122 function than size, with the traditional two-diameter class approach overestimating absorptive 123 root length by $25 \%$ (Guo et al., 2008b). The response to these findings by some has been to 124 classify fine roots into more size classes (e.g., Park et al., 2008). However, another approach 125 may be to identify functional breaks across root orders or size classes. For example, first and 126 second order roots may be classed together as ephemeral root modules with high rates of 127 respiration, uptake and turnover, while higher order roots with secondary development are 128 assumed to have limited uptake capacity and function more for transport and storage (Xia et al., 129 2010).

Although species differ in their growth and resource acquisition, identifying roots to the 131 species-level in a mixed-species ecosystem is not a simple task and more field method 132 development is needed. Visually distinguishing among roots of some hardwood species requires 133 tracing each distal, fine root to a larger root (> $2 \mathrm{~mm}$ diameter) to examine its secondary growth 134 (Yanai et al., 2008), which is time-consuming and not always feasible. Genetic approaches can 135 be used to identify single root fragments to species using polymerase chain reaction techniques 
136 (Bobowski et al., 1999), but their use remains rare. Species can also be identified in bulked root 137 samples (Fisk et al., 2010; Mommer et al., 2008), though there remain concerns about time constraints (Fisk et al., 2010) and biases based on species and root size (Yanai et al., 2008). Additionally, root systems must be contextualized in terms of their mycorrhizal status, which fundamentally influences root function and ecosystem dynamics. As has been long 141 appreciated, the extramatrical hyphae of mycorrhizae increase surface area for water and nutrient 142 absorption, with the effect varying by fungal species (Agerer, 2001) and ion mobility (Bolan, 143 1991; Eltrop and Marschner, 1996). Mycorrhizal communities are influenced by disturbances 144 such as fire or elevated nutrient concentrations (Treseder et al., 2007) with potentially significant 145 influences on ecosystem function. However, in situ measurements of mycorrhizal influences on 146 whole root system dynamics remain sparse, given that it is difficult to isolate root function 147 between mycorrhizal and non-mycorrhizal roots and because extramatrical fungal hyphae are 148 often severed when the roots are excavated (Bloom and Caldwell, 1988). Thus, developing 149 quantifiable relationships between fungal-root associations and ecosystem function remain 150 elusive; yet, there have been increasing calls for improved representation of microbial 151 communities in ESMs. Treseder et al. (2012) suggested that modeled decomposition rates could 152 benefit from the inclusion of second-order dynamics dependent on microbial biomass. Specific 153 to mycorrhizal associations, the increasing availability of regionally and globally extensive data 154 (e.g., Öpik et al., 2013), together with increased analytical understanding of root-mycorrhizal 155 relationships (e.g., Clemmensen et al., 2013), suggests that incorporation of these dynamics into 156 regional and ESMs is now tractable. In sum, despite increasing recognition of alternative root classification strategies

158 regarding species, rooting order, and fungal associations, many models continue to segregate 
159 roots by size classes. This size categorization may serve to represent the functional duality of

160 having both shorter-lived, absorptive roots and longer-lived, transport or structural roots,

161 independent of whether they are termed "fine" or "coarse". However, additional testing of

162 alternative root classification strategies would allow for exploration of functional implications of

163 root structure on terrestrial C, water, and nutrient dynamics (Gaudinski et al., 2010).

164

165

166

167

168

169

170

171

172

173

174

175

176

177

178

179

180

181

\section{Root Production}

Field-based estimates are often used to improve parameterization of root production in models. However, measurement of root production in situ is time-consuming and fraught with measurement error. For example, ingrowth cores involve the removal of all roots from a soil core, after which the clean, root-free soil is returned; the core is revisited after a given period of time and the amount of new roots that have grown into the core is used to represent root production over that time. However, the process of inserting the initial core into the soil severs roots and may elicit a wounding response from neighboring roots and increase local production above normal levels in the short-term (Hendricks et al., 2006). Minirhizotrons are also used to estimate production but installation of minirhizotron tubes artificially increases root production for one to three years. Minirhizotron measurements of observed root length or root number also must be converted to production estimates on a $\mathrm{g} \mathrm{m}^{-3}$ basis that, ironically, are best derived using site-specific information of root biomass from soil cores and information about soil volume or depth (but see Taylor et al., 2014). Ultimately, the most reliable approach for estimating root production is through sequential coring campaigns, but the frequency and intensity required to compensate for the high spatial heterogeneity observed in natural systems often prohibits this approach. These methods, together with a few others (e.g. budgeting approaches) provide the 
182 basis for most estimates of root production. The strengths and weaknesses of each method is

183

184 185

186

187

188

189

190

191

192

193

194

195

196

197

198

199

200

201

202

203

204

covered more thoroughly in previous reviews (Hendricks et al., 2006; Milchunas, 2009; Ostonen et al., 2005; Smit et al., 2000; Vogt et al., 1998).

In models, root production is commonly allocated as a fixed proportion of recent photosynthate (Fig. 2a), to maintain a fixed ratio between biomass pools such as roots and leaves (Harmon, 2011; Keane et al., 2011) (Fig. 2b), or only after allocation to other aboveground pools (Fig. 2c). Many models assume allocation is optimized to meet plant demands for nutrients, growth, light, or survival (Bloom et al., 1985; Brassard et al., 2009; Ingestad and Agren, 1991; Johnson and Thornley, 1987; Poorter and Nagel, 2000) but adjust the allocation dynamically based on environmental conditions. For example, the CENTURY model adjusts root allocation as a function of annual precipitation, with increasing rainfall resulting in reduced root allocation (Metherell et al., 2010). Similarly, the Community Land Model (CLM) begins with a fixed ratio of $\mathrm{C}$ allocation between leaves and fine roots, which is then shifted to favor allocation to fine roots as water stress increases (Levis et al., 2004). CLM-Carbon-Nitrogen (CLM-CN) shifts allocation from roots to woody stems during favorable growth years (Oleson et al., 2010). Interestingly, in a global meta-analysis, Yuan and Chen (2012) showed that relaxation of nutrient limitations has a greater influence on aboveground versus belowground production. However, other factors, such as tree ontogeny, seasonality and differences among individuals, species, and communities, can also mediate dynamic allocation between root, leaf and wood production.

The phenology of root production is also important, describing how plants utilize temporally-variable water and nutrient resources during the growing season. Efforts to record leaf phenology have increased in recent years since climate change affects spring leaf emergence and fall leaf senescence (Diez et al., 2012; Fridley, 2012; Richardson et al., 2012), but few 
scientists document phenology in roots. Root production may occur at different rates and starting points throughout the growing season and may not be synchronous with aboveground productivity. Field studies suggest that asynchronicity in root and shoot phenology is present in 208 both woody species and grasses, and may be significant, ranging from 2 weeks to 2 months 209 (Steinaker et al., 2010). Recent studies have also shown that new roots may be constructed from $210 \mathrm{C}$ acquired in previous growing seasons and stored within the plant, as opposed to only recently 211 acquired photosynthate (Gaudinski et al., 2009; Vargas, 2009). This allows for the possibility 212 that, at times, root production may be entirely decoupled from active photosynthesis (Oleson et 213 al., 2010; Schaefer et al., 2008; Shevliakova et al., 2009; Zaehle and Friend, 2010), and that 214 models should incorporate lag effects across seasons and years.

215 In models, phenology is primarily expressed through the seasonality of aboveground 216 vegetation, i.e. leaf area index (Oleson et al., 2010; Richardson et al., 2012), and roots are 217 influenced indirectly through allocation paradigms described above. As a result, root production 218 is effectively limited to the active growing season, which likely serves as a reasonable first order 219 approximation. Encouragingly, some models explore more detailed descriptions of whole plant 220 phenology. The effects of soil temperature on root turnover and respiration (e.g., the Ecosystem 221 Demography model (ED2: Medvigy et al., 2009) and changes to constrain C allocation for 222 woody stem growth to a shorter period that reflects observed phenology of stem growth (e.g., 223 ForCENT; Parton et al. 2010) are recent examples. It may also be possible to limit root 224 production to earlier or later parts of the growing season to reflect patterns for particular species 225 or PFTs. For example, observations of root phenology in a common garden experiment found 226 that root production in some species generally peaked around mid-June (e.g. Liriodendron 227 tulipifera) while others peaked in mid- to late-July (e.g. Pinus spp) (McCormack et al., in press). 
228 Another modeling approach allows for a root storage pool, as has been found in experimental

229 studies (Gaudinski et al., 2009; Vargas, 2009), which may allow for lagged responses. More

230 empirical studies that provide data of sufficient temporal resolution to allow for identification of

231 generalizable patterns of root production phenology (Burton et al., 2000; McCormack et al., in

232 press; Steinaker et al., 2010) would improve the simulation of seasonal root production in

233 terrestrial models.

\section{Root turnover}

Modelers often treat turnover as, simply, the inverse of lifespan. Technically, fine root

237 turnover rate represents the number of times a population of roots is replaced during a given time

238 period (e.g. annually) and can incorporate information regarding root production, standing

239 biomass, and lifespan. Empirically, turnover is variably calculated, yielding comparable but

240 slightly different estimates of turnover. For example, if turnover is calculated as

241 production/standing biomass, a single observation of root production measured as $1000 \mathrm{~g} \mathrm{~m}^{-2} \mathrm{yr}^{-1}$

242 might be combined with standing root biomass measured 5 times over the course of a year at

$243700,10001300,1100,900 \mathrm{~g} \mathrm{~m}^{-2}$, resulting in turnover estimates of $0.77,1.4$, or $1.0 \mathrm{yr}^{-1}$

244 depending on whether maximum, minimum, or average standing biomass was used in the

245 calculation. Additionally, fine root turnover rates have been calculated as the inverse of observed

246 fine root lifespan, which also may produce similar estimates of turnover as other methods but

247 never the quite the same. Overall, an important first step in modeling fine root turnover is

248 recognizing differences in methods for calculating turnover and appreciating potential bias

249 among the different methods (McCormack et al., in press). 
In addition to variation due to methodology, many studies have highlighted real and

251 substantial variation in root turnover rate both across and within sites and species (Gill and

252 Jackson, 2000; Iversen et al., 2008; McCormack et al., in press; Withington et al., 2006).

253 Globally, there is likely to be close to an order of magnitude of variation in measured turnover

254 rates. Importantly, this level of variation may also exist at the site level due to variation among

255 species or across years. However, because calculations of turnover rate often involve estimates

256 of production, mortality and standing biomass, it is not always clear whether this variation is due

257 to consistent differences in root longevity and replacement or short-term (season to annual)

258 changes in production or mortality. Furthermore, within a single root branch, turnover times of

259 distal roots active in resource absorption typically range from months to a few years while

260 turnover times of more proximal, resource conducting fine roots are frequently in excess of a

261 decade (Gaudinski et al., 2010). Therefore, some of this variation may be due simply to the pool

262 of roots that is most emphasized by different methods. Minirhizotron cameras enable direct

263 observation and measurement of root lifespan of fine roots. Additionally, isotopic tracers have

264 been used to measure residence times of root $\mathrm{C}$ to calculate turnover rates (Gaudinski et al.,

265 2010; Matamala et al., 2003), but tracers tell more about when C was fixed and don't directly

266 quantify root age. Each approach (traditional coring, minirhizotrons, isotopes) has strengths and

267 weaknesses that have been discussed extensively elsewhere (Gaudinski et al., 2010; Guo et al.,

268 2008a; Tierney and Fahey, 2002) and much of the reliability of each method to estimate root

269 turnover depends on which root pool is of interest. In general, minirhizotrons are likely better

270 suited for determining lifespan and turnover times of the more ephemeral, absorptive fine roots

271 while isotopes may be more appropriate for higher order, longer-lived fine roots and coarse

272 roots. 
Even accepting differences in terminology and accepting a more traditional view of turnover as equal to root mortality requires the understanding that the causes of root mortality are

275 diverse, and include decomposition, herbivory (Hendrick and Pregitzer, 1992), and direct

276 physiological stress. Root herbivory may be important in many systems and differentially affect

277 agricultural systems that are designed to minimize harmful microbial and fungal activity versus

278 natural systems. Other causes of mortality, including cellular toxicity to adverse

279 biogeochemical environments (Cronan and Grigal, 1995) may be important in regions subjected

280 to elevated $\mathrm{N}$ deposition (Smithwick et al., 2013). The importance of these mortality factors has 281 not been explored at regional or global scales.

Though often included in models, root turnover is poorly constrained and contributes 283 significantly to model uncertainty (Ciais et al., 2008; Malhi et al., 2011). Understanding these uncertainties is likely to remain a critical task for unraveling the often complex and contradictory

285 implications of turnover on total ecosystem C. For example, increased root allocation could 286 increase resource availability or uptake thereby increasing ecosystem $\mathrm{C}$ stocks, or decrease 287 ecosystem $\mathrm{C}$ stocks by increasing respiratory $\mathrm{C}$ losses or decreasing allocation to aboveground 288 plant parts (Fig. 3a). At the same time, even constant allocation rates could alter ecosystem C 289 stocks if root biomass is independently altered (Smithwick et al., 2013) (Fig. 3b). The relative 290 balance of these processes remains critical in contemporary model frameworks and reinforces the 291 importance of uncertainty analyses focused on turnover dynamics.

While turnover remains a fixed parameter in many models, other models allow root turnover rates to vary as functions of environmental factors such as $\mathrm{N}$ mineralization rate in 294 PnET-CN, (Aber et al., 1997; Ollinger et al., 2002) or soil water content and temperature in ED2 295 and ForCENT. In LANDIS-II, FORCS Extension, fine root turnover may temporarily increase 
to reflect a loss of aboveground biomass due to branch mortality or disturbance (Dymond et al.,

297 2012). These and other similar approaches may enable more complete descriptions of root

298 dynamics into models, though the accuracy of these efforts will depend on the ability to

299 accurately link variation in root turnover rates to changes in environmental factors and

300 ecosystem dynamics.

301 Directed field efforts will certainly improve estimates of root turnover rates available for

302 models and may identify useful relationships between root turnover and environmental

303 conditions. Information based on fine root lifespan, rather than more sophisticated definitions of 304 turnover described above, are more widely available via expanded use of minirhizotrons and C

305 isotopes. Applied at broad scales, root turnover may prove to be useful as an output variable and 306 diagnostic tool for modelers to determine whether belowground $\mathrm{C}$ fluxes are within a reasonable 307 range or how modeled systems respond given different environmental conditions or

308 perturbations. However, a key consideration is careful attention to turnover parameters derived 309 from field data that may differ across methods and employ different terminology.

\section{Root biomass}

Data that adequately capture spatial and temporal variation in root biomass are rare. As 313 with production, seasonal and interannual variation in root standing crop is large, attributed to 314 changes in resource availability (Hendricks et al., 1993; Nadelhoffer, 2000), tree size (Yuan and 315 Chen 2012a), climate (Lee et al., 2007), and species (McCormack et al., in press). As described 316 above, soil cores or pits can be used to measure root biomass and are technically simple, but are 317 notoriously labor intensive. Other approaches are available, including ground-penetrating radar 318 (Butnor et al., 2003), but radar primarily measures coarse root biomass with little seasonal 
319 variation, is technically challenging, and still necessitates validation using soil cores (Stover et 320 al., 2007).

In the absence of direct measurements, root biomass can be estimated using allometry.

322 However, surprisingly few studies collect both above- and belowground biomass of vegetation in 323 situ across landscape gradients in stand ages and vegetation composition (Kashian et al., 2013;

324 Santantonio et al., 1977). Vadeboncoer et al. (2007) estimated that, across 12 northern hardwood 325 stands in New Hampshire (USA), allometric equations provided accurate estimates of lateral 326 roots (coarsely defined as $<10 \mathrm{~cm}$ diameter) when stands were greater than 20 years old (mean 327 error 24 to $32 \%$ ), but underestimated root biomass by greater than $60 \%$ among young stands. 328 This result is consistent with the assertion that allometry underestimates root biomass by ca. $60 \%$ 329 (Robinson, 2004). In sum, although conceptually straight-forward, estimating the standing crop 330 of roots is surprisingly difficult and rarely validated at the site or landscape level. Estimation of root standing crop can be used to initialize model pool sizes but these direct 332 estimates are rare and fraught with error. Thus, in the absence of direct estimates at global 333 scales, modelers rely on surrogates for estimating root biomass, such as fixed relationships 334 between foliar, woody or total aboveground biomass (Wolf et al., 2011). The specific approach 335 used differs among models, highlighting differences in understanding of the factors that govern 336 root biomass. For example, one approach has been to simulate fine roots as a function of leaf 337 biomass; and, using similar logic, coarse roots as analogous to, and a fixed fraction of, woody 338 biomass, as is implemented in the current version of LANDIS-II, Century extension (Scheller et 339 al., 2011). This assumes that fine roots are functionally similar to leaves, acting as belowground 340 scavengers of resources. However, these relationships are often held constant across species, 341 PFT, and site conditions, with unknown implications on model outcomes. Furthermore, as leaves 
342 and fine roots are frequently exposed and respond to vastly different environmental pressures, it

343 is unclear how consistent these relationships are in nature and how flexible they should be in

344 models. Wolf et al. (2011) showed that land surface models which incorporated stand-thinning

345 processes or shorter wood turnover times performed better related to observed allometries.

346 Ultimately, root biomass is the net result of root production (gain) and turnover (loss) that each

347 change over time. In practice, root biomass or its associated rates (production,

348 turnover/mortality) are often used to 'tune' model responses, given that it's 'true' value is not

349 known. Thus, constraints on pool sizes (minimum, maximum) are sorely needed to bound model

350 estimates of root biomass.

\section{Resource Uptake \& Rooting Depth}

Resource uptake by roots can be measured using a combination of direct or proxy

354 estimates. Water uptake can be measured directly using sapflow gauges (Brooks et al., 2002),

355 but involves excavation of individual roots and/or sometimes the use of caves to access deep

356 roots (Bleby et al., 2010). Directly measuring nutrient uptake in intact root systems in the field is

357 equally difficult (for a review see Lucash et al., 2007). A few recent studies have measured

358 nutrient uptake in sand with intact mycorrhizal roots (Lucash et al., 2008) using labeled isotopes

359 (Proe et al., 2000) and intact soil with isotopic pulse-chase experiments in large plants and trees

360 (e.g., Soethe et al., 2006). These studies assume that soil nutrients are not limiting and uptake

361 rates are constant across concentration (but see Lucash et al., 2007), and are seldom linked with

362 measurements of resource availability or plant demand.

Estimating uptake from the difference of other measured fluxes has been measured at

364 annual scales (Gessler et al., 1998; Nadezhdina et al., 2008). However, at finer temporal scales, 
total uptake may differ in response to daily and seasonal patterns in climate and/or resource availability (Gessler et al., 1998). An additional constraint to budgeting approaches is that they are often calculated at the stand-level, precluding any ability to quantify uptake at the specieslevel, except in monocultures. However, root uptake may be spatially heterogeneous within the soil profile even if total uptake remains unchanged due to localized patterns in water and nutrients (Garrigues et al., 2006; Sharp and Davies, 1985; Wan et al., 2002), which would be difficult to quantify through annual budgeting approaches at the stand level. The degree to which spatial and temporal patterns in root uptake is due to shifts in allocation, active plant regulation of the soil environment, and/or a response to abiotic gradients in water potentials and nutrient gradients that govern mass flow, is an active area of research.

Recent modeling efforts have highlighted the need to understand resource (nutrients, water) availability to capture observed behaviors and lend credibility to predicted responses of terrestrial vegetation to climate change (Thornton et al., 2007). Given that roots determine nutrient uptake, it is surprising that uptake is commonly modeled indirectly. For example, many models simulate water or nutrient uptake as a function of soil resource availability, weighted by the relative root fraction or relative root length density within a soil layer, relative to leaf demand, which is a function of either canopy biomass or productivity (Dybzinski et al., 2011; Hopmans and Bristow, 2002; Keane et al., 2011; Li et al., 2012; Medvigy et al., 2009; Metherell et al., 2010; Scheller et al., In press). The influence of roots is indirect in that rates of root turnover affect the soil $\mathrm{N}$ cycle and $\mathrm{N}$ availability, while leaf $\mathrm{C}$ to $\mathrm{N}$ ratios determine actual uptake. However, recent efforts coupling $\mathrm{C}$ and $\mathrm{N}$ dynamics using second generation dynamic global vegetation models (Tian et al., 2011; Zaehle and Friend, 2010) and modular approaches such as the Fixation and Uptake of Nitrogen module (FUN) by Fisher et al. (2010) incorporate 
root-level physiology to model $\mathrm{N}$ uptake and transport and allow for dynamic patterns of allocation. Li et al. (2012) recently tested alternate root functions in a land surface model (CABLE - Community Atmosphere Biosphere Land Exchange model) to simulate how water uptake and hydraulic redistribution affected net ecosystem exchange. Including these root dynamics significantly improved agreement between eddy flux tower observations and modeled fluxes of $\mathrm{CO}_{2}$, latent heat flux, and soil moisture dynamics. Optimization theory has also been used to simulate $\mathrm{N}$ uptake; for example, McMurtrie et al. (2012) proposed that rooting mass be distributed dynamically in response to the spatial variability of soil $\mathrm{N}$ so as to maximize $\mathrm{N}$ uptake.

Even as indirect methods of modeling resource uptake are being challenged, there remains much room for model improvement. Changes in the soil environment are likely to affect nutrient uptake rates and efficiencies via changes in root tissue physiology. Smithwick et al. (2013) reviewed this effect for $\mathrm{N}$ deposition, highlighting root physiological studies that have indicated tissue level stress as a function of elevated chemical environments. Understanding mechanisms of root physiology, e.g., concentration thresholds of toxic elements that influence lifespan, remains a frontier in modeling that would benefit from increased interdisciplinary dialogue. Similarly, inclusion of how mycorrhizal fungi affect root uptake is also important (Orwin et al., 2011) particularly for immobile nutrients like phosphate (Smith and Read, 2008). Mathematical modeling of individual roots indicates that phosphate uptake is dominated by hyphal and not root uptake (Schnepf et al., 2008b). Also, recent efforts to simulate the development and extent of the fungal mycelium will be helpful for interpreting species differences in foraging strategies and how this might affect nutrient acquisition (Schnepf et al., 2008a). Finally, most models ignore the fact that nutrient and water uptake take place only at 
411 the surface of roots, potentially independent of total root biomass. Empirical studies indicate that

412 specific root length (length per unit mass, $\mathrm{m} \mathrm{g}^{-1}$ ) and surface area can vary by an order of

413 magnitude between species (Comas and Eissenstat, 2009; Tjoelker et al., 2005), which may

414 dramatically affect resource uptake.

415 Given that rooting depth affects nutrient and water uptake (Dawson, 1995; Göransson et 416 al., 2006; Kulmatiski and Beard, 2012), it is important to understand how rooting depth varies 417 across species and sites (Göransson et al., 2006; Kulmatiski et al., 2010). Most experimentalists 418 confine their measurements of root processes to the upper 10 or $20 \mathrm{~cm}$ of soil because most fine 419 roots are located in surface layers. For example, (Soethe et al., 2006) found that 32 to $43 \%$ of

420 the total $\mathrm{N}$ taken up by trees, shrubs and herbs was obtained from the organic layer, while only 2 421 to $19 \%$ was derived from a soil depth of $40 \mathrm{~cm}$. However, several studies, e.g., free-air- $\mathrm{CO}_{2^{-}}$ 422 enrichment (FACE) experiments, have shown the greatest increases in root mass occurred at soil 423 depths below $30 \mathrm{~cm}$ (Iversen, 2010), leading to greater $\mathrm{N}$ extraction from depth, either due to 424 increased $\mathrm{N}$ availability or deeper rooting (Iversen et al., 2008). In some arid systems, pools of $425 \mathrm{P}, \mathrm{Ca}$ and $\mathrm{Mg}$ at 2-3 m depth appear to be utilized by deep roots (McCulley et al., 2004); other 426 studies have shown maximum rooting depths from $5 \mathrm{~m}$ to $25 \mathrm{~m}$ (Jackson et al., 1999). Deep 427 roots may be particularly important in arid systems where trees utilize groundwater as their 428 primary water sources (Dawson, 1996) but may also be important in wet, tropical environments 429 during periods of low rainfall (Davidson et al., 2011). Plants can also modify their resource 430 environment by depth through hydraulic redistribution (Amenu and Kumar, 2008; Bleby et al., 431 2010; Jarvis, 2011; Simunek and Hopmans, 2009), the effects of which vary dramatically across 432 ecosystems (Neumann and Cardon, 2012). Rooting depth may also be responsive to preferred 433 flow paths in soils. As a result of these and other processes, the source of water utilized by plants 
434 can vary seasonally, with soil conditions, and with depth (Bertrand et al., 2012; Yang et al., 435 2011).

Modeling water extraction by depth has been undertaken at various levels of

437 sophistication (Fig. 4). In the simplest 'bucket model' approach (Budyko, 1974; Manabe, 1696),

438 the subsurface is represented as a single layer, with transpiration evenly extracted throughout the

439 soil column. In models that represent the subsurface with multiple soil layers, the rooting

440 architecture of vegetation is described with temporally and spatially invariant macroscopic

441 parameters such as root depth and/or root shape that are dictated by the type of vegetation being

442 modeled (Feddes et al., 2001; Pitman, 2003; Schenk and Jackson, 2002). Typically, these models

443 distribute the transpiration based on upon the fraction of roots that reside in each soil layer.

444 Parameterization of the root profile is often only determined by empirical data organized by PFT

445 which may not directly match the vegetation classifications found in many ESMs (Zeng, 2001).

446 Moreover, these parameters do not consider local abiotic and biotic interactions. Jackson et al.

447 (2000) details the various model treatments of root distribution, highlighting that rooting

448 parameters are frequently determined independently of local soil texture and climatic region. As

449 a consequence, these models do not take into account the strong influence that soils and climatic

450 variability have on the partitioning of precipitation at the surface and the flow of moisture

451 through the root zone. This simplification also ignores the long history of observational data

452 (Weaver 1926) that recognized that under myriad soil textures or precipitation regimes the same

453 plant species can exhibit alternative rooting strategies to cope with different belowground

454 moisture distribution (Caylor et al., 2006; Gentine et al., 2012). Through a series of synthetic

455 simulations, Sivandran and Bras (2012) illustrated the influence of local abiotic conditions on

456 determining the optimal rooting depth and extended this work to include a dynamic root $\mathrm{C}$ 
457 allocation algorithm driven by the vertical distribution of soil moisture (Sivandran and Bras,

458 2013). By allowing the belowground rooting structure to adapt and evolve with local soil,

459 topography and climatic conditions, improvement of water, energy and C fluxes was achieved.

460 Several studies have applied the evolutionary principle which states that environmental

461 (abiotic) and competitive (biotic) pressures have resulted in a set of species that have adapted to

462 the local conditions by expressing traits that maximize the benefit to the plant and improve the

463 probability of success of the individual. Kleidon and Heimann (1998) applied this philosophy to

464 optimize the depth of a bucket model for different vegetation classes forced with climate data

465 and soil texture information. They observed increases in ANPP as a result of using an optimized

466 root depth parameter rather than the model default values.

467 Physically-based modelling approaches that resolve the soil water flow, plant water

468 uptake and the impact of soil characteristics within a three-dimensional representation of the root

469 system have begun to produce the required functional relationships needed by larger scale

470 models (Couvreur et al., 2012; Javaux et al., 2013). In fact, Javaux et al. (2012) outlined a

471 methodology by which physically-based models can inform the parameterization of large-scale

472 models that, due to their scale, necessitate the use of macroscopic parameters.

473 Recently, authors have explored the role of rooting depth and distribution on a wide

474 variety of ecological responses (Collins and Bras, 2007; Guswa, 2008; Hildebrandt, 2005;

475 Hwang et al., 2009; Lai and Katul, 2000; Schenk, 2008; Schymanski et al., 2008; Schymanski et

476 al., 2009). For example, using the model MC1 (MAPPS-Century 1), Daly et al. (2000) explored

477 the influence of rooting depth of trees and grasses on $\mathrm{C}$ and nutrient fluxes in Wind Cave

478 National Park, South Dakota, USA. Results showed significant influence of rooting depth on

479 model outcomes. In particular, rooting depth had a larger effect than climate on biogeochemical 
480 pools under both historical and future climate scenarios. Deeper roots increased vegetation 481 productivity and modified fire regimes through competitive interactions with grasses. At the

482 global scale, the lack of representation of deep water access may explain why ESMs cannot 483 simulate adequately the response of tropical forests to seasonal drought (Baker et al., 2008).

484 Even if root profiles can be identified empirically for given plant types, these results suggest that 485 dynamic profiles are necessary to emulate vegetation resilience under increasingly common 486 global change factors such as drought. In conclusion, although model structural and functional 487 flexibility to rooting depth profiles is currently being implemented in models (e.g., Li et al., 488 2012; McMurtrie et al., 2012; Sivandran and Bras, 2013), implications of these changes on total 489 model responses must be explored across broader gradients of environmental conditions.

SYNTHESIS \& RECOMMENDATIONS

In the traditional view of root dynamics in regional ecosystem models and ESMs (Fig.

493 5a), allocation governs root production, influencing the root $\mathrm{C}$ stock available for turnover, 494 which in turn governs soil $\mathrm{C}$ and nutrient dynamics. In these black box approaches, roots 495 indirectly respond to altered conditions but do not themselves influence their environment or 496 whole-plant function directly, which is known to be an overly simplistic assumption. Notably, 497 these dynamics are persistently guided by only a few key principles, e.g., dynamic and/or 498 optimum allocation, or the evolutionary principle. While these principles are reasonable at global 499 scales, they obviate the need to model root uptake directly through physiological mechanisms, 500 precluding prognostic understanding of root responses to global change drivers. In addition, 501 through experimentation and observation, several shortcomings are additionally evident in model 502 approaches to root dynamics, such as the general lack of representation of mycorrhizal-root 
503 associations, limited attention to root phenology or stored $\mathrm{C}$ pools, and the simulation of uptake 504 rates conditioned on biomass or demand rather than active surface area. Perhaps most strikingly, 505 the factors that govern root lifespan and influence root mortality directly are not included, such 506 as herbivory or physiological tissue stress.

507 Given the literature reviewed here, we propose a new framework that illuminates a more 508 nuanced understanding of root dynamics (Fig. 5b). In this new understanding, feedbacks from 509 roots to aboveground pools and fluxes may result in behavior that is not captured by treating 510 roots as 'passive portals' or 'black boxes'. In this new framework, we propose that earth system 511 modelers could incorporate changes into their existing frameworks (Table 1), while encouraging 512 empirical scientists to collect data at the temporal and spatial resolution necessary for modeling 513 at a large spatial scale.

514 To enable a community of modelers to test these and other changes in root function on 515 ecosystem function, we have identified the following research opportunities that cut across the 516 specific tests described above (Table 2). First, models must include roots in data assimilation, 517 variance partitioning, and optimization. These approaches should explore the effect of parameter 518 and structural uncertainty and identify conditions that lead to threshold responses. Models that 519 do not have significant feedbacks between belowground pools to aboveground function are likely 520 to have little internal sensitivity to root parameters or algorithms, whereas models that couple 521 roots to nutrient or water availability with feedbacks to aboveground function are likely to be 522 influenced heavily by belowground dynamics. Using this approach with ED2, it has been shown 523 that allocation, turnover, and water conductance (which moderates root water uptake), have high 524 parameter variance and can contribute significantly to overall model sensitivity (LeBauer et al., 525 2013; Wang et al., 2012). 
Second, it is critical that global datasets become increasingly available, taking the

527 'guesswork' out of root parameterization. This is dependent on several factors, including the

528 coalescence of existing data sets to archives that modelers are able to access readily (e.g.,

529 Gordon and Jackson, 2003), as well as methodologies that encourage new field data to be

530 obtained in regions that are currently data-sparse. Particularly important is the identification of

531 target ecosystems in which small investments in data retrieval will aid global upscaling efforts.

532 In the development of globally available datasets, database management must include the

533 prioritization of key parameters, and identification of protocols and criteria for empirical data

534 collection. Given the confusion over even common terms such as 'turnover', and differences

535 among methodologies, careful attention here is critical. Widespread use of global root datasets

536 in models is emerging for some key variables, e.g., rooting profiles (Schenk and Jackson, 2002)

537 but is not widely available for other parameters such as root lifespan. Additional studies are

538 needed to link the distribution of mycorrhizal species or functional types with root function in a

539 manner that facilitates incorporation of mycorrhizas into simulation models.

540 Third, contemporary root physiological studies, some of which are highlighted in this

541 review, foretell of a substantial opportunity to develop improved mechanistic feedbacks between

542 aboveground and belowground pools. If tissue-level root functions can be related

543 physiologically to key ecosystem processes, as has been widely accepted for photosynthesis in

544 leaves (Farquhar et al., 1980), it will be possible to explore how roots directly influence and are

545 influenced by the soil environment and aboveground systems.

546 While model improvements of root function may seem daunting, it is equally true that

547 significant empirical understanding of root function has emerged in recent years. Significant

548 interdisciplinary work and collaboration between empiricists and modelers is still needed to 
549 guide data collection and model improvement. Yet, the new framework shown here highlights 550 an opportunity to incorporate new functionality into models with the goal of developing field-

551 testable hypotheses. Modelers must increasingly strive to quantify root activity, request data

552 where needed, and use models to develop testable hypotheses about root function. While staying

553 honest to available data, modelers have an opportunity to challenge widely held paradigms and

554 to explore tradeoffs - both mechanistic and computational - in improving root function in

555 models. The goal of this effort ought to be increasing the coupling between leaves, roots and

556 soil, and further constraining model predictions of terrestrial ecosystem responses to global

557 change drivers. The degree to which these additional changes, e.g., splitting roots into explicit

558 functional versus size classes, or including fungal-root associations, may be required to

559 accurately forecast ecosystem resilience to global change must be weighed against costs in 560 model complexity and increased model variance.

562 ACKNOWLEDGEMENTS

563 The manuscript was conceived during a DOE and NSF-sponsored workshop on root-model 564 dynamics (DOE NSF DEB 1227828). This work was partially supported by a U.S. Department 565 of Energy GREF and from Research Fellowships from the Chinese Academy of Sciences and 566 National Natural Sciences Foundation of China (NSFC) for Young International Researchers 567 (No. 31350110503) to MLM. The authors wish to thank Michael Dietze and Anthony Walker for 568 constructive comments on an earlier version of the manuscript. 


\section{REFERENCES}

Aber, J., Ollinger, S.V., Driscoll, C.T., 1997. Modeling nitrogen saturation in forest ecosystems in response to land use and amospheric deposition. Ecol Model 101, 61-78.

Agerer, R., 2001. Exploration types of ectomycorrhizae. Mycorrhiza 11, 107-114.

Albani, M., Medvigy, D., Hurtt, G.C., Moorcroft, P.R., 2006. The contributions of land-use change, $\mathrm{CO} 2$ fertilization, and climate variability to the Eastern US carbon sink. Global Change Biol 12, 2370-2390.

Amenu, G.G., Kumar, P., 2008. A model for hydraulic redistribution incorporating coupled soilroot moisture transport. Hydrology and Earth System Sciences 12, 55-74.

Baker, I.T., Prihodko, L., Denning, A.S., Goulden, M., Miller, S., da Rocha, H.R., 2008. Seasonal drought stress in the Amazon: Reconciling models and observations. J. Geophys. Res. 113, G00B01.

Bertrand, G., Masini, J., Goldscheider, N., Meeks, J., Lavastre, V., Celle-Jeanton, H., Gobat, J.M., Hunkeler, D., 2012. Determination of spatiotemporal variability of tree water uptake using stable isotopes $(\delta 18 \mathrm{O}, \delta 2 \mathrm{H})$ in an alluvial system supplied by a high-altitude watershed, Pfyn forest, Switzerland. Ecohydrology, n/a-n/a.

Bleby, T.M., McElrone, A.J., Jackson, R.B., 2010. Water uptake and hydraulic redistribution across large woody root systems to 20 m depth. Plant, Cell \& Environment 33, 21322148.

Bloom, A.J., Caldwell, R.M., 1988. Root Excision Decreases Nutrient Absorption and Gas Fluxes. Plant Physiology 87, 794-796.

Bloom, A.J., Chapin, F.S., Mooney, H.A., 1985. Resource limitation in plants - an economic analogy. Ann Rev Ecol Syst 16, 363-392. 
Bobowski, B.R., Hole, D.J., Wolf, P.G., Bryant, L., 1999. Identification of roots of woody species using polymerase chain reaction and RFLP analysis. . Molecular Ecology 8, 485491.

Boisvenue, C., Running, S.W., 2010. Simulations show decreasing carbon stocks and potential for carbon emissions in Rocky Mountain forests over the next century. Ecol Appl 20, 1302-1319.

Bolan, N.S., 1991. A critical review on the role of mycorrhizal fungi in the uptake of phosphorus by plants. Plant Soil 134, 189-207.

Brassard, B.W., Chen, H.Y.H., Bergeron, Y., 2009. Influence of environmental variability on root dynamics in northern forests. Critical Reviews in Plant Science 28, 179-197 \%@ 0735-2689.

Brooks, J.R., Meinzer, F.C., Coulombe, R., Gregg, J., 2002. Hydraulic redistribution of soil water during summer drought in two contrasting Pacific Northwest coniferous forests. Tree Physiology 22, 1107-1117.

Budyko, M.I., 1974. Climate and Life. Academic Press, New York 508 pp.

Burton, A.J., Pregitzer, K.S., Hendrick, R.L., 2000. Relationships between fine root dynamics and nitrogen availability in Michigan northern hardwood forests. Oecologia 125, 389399.

Butnor, J.R., Doolittle, J.A., Johnsen, K.H., Samuelson, L., Stokes, T., Kress, L., 2003. Utility of Ground-Penetrating Radar as a Root Biomass Survey Tool in Forest Systems. Soil Sci. Soc. Am. J. 67, 1607-1615.

Caylor, K.K., D'odorico, P., RodríGuez-Iturbe, I., 2006. On the ecohydrology of structurally heterogeneous semiarid landscapes. Water Resources Research 42, WO7424. 
617 Ciais, P., Schelhaas, M.J., Zaehle, S., Piao, S.L., Cescatti, A., Liski, J., Luyssaert, S., Le-Maire,

G., Schulze, E.D., Bouriaud, O., Freibauer, A., Valentini, R., Nabuurs, G.J., 2008.

Carbon accumulation in European forests. Nature Geoscience 1, 425-429.

Clemmensen, K.E., Bahr, A., Ovaskainen, O., Dahlberg, A., Ekblad, A., Wallander, H., Stenlid, J., Finlay, R.D., Wardle, D.A., Lindahl, B.D., 2013. Roots and Associated Fungi Drive Long-Term Carbon Sequestration in Boreal Forest. Science 339, 1615-1618.

Collins, D.B.G., Bras, R.L., 2007. Plant rooting strategies in water-limited ecosystems. Water Resources Research 43.

Comas, L.H., Eissenstat, D.M., 2009. Patterns in root trait variation among 25 co-existing North American forest species. New Phytol 182, 919-928.

Couvreur, V., Vanderborght, J., Javaux, M., 2012. A simple three-dimensional macroscopic root water uptake model based on the hydraulic architecture approach. Hydrology and Earth System Sciences 16, 2957-2971.

Cronan, C.S., Grigal, D.F., 1995. Use of calcium aluminum ratios as indicators of stress in forest ecosystems. Journal of Environmental Quality 24, 209-226.

Daly, C., Bachelet, D., Lenihan, J.M., Neilson, R.P., Parton, W., Ojima, D., 2000. Dynamic simulation of tree-grass interactions for global change studies. Ecol Appl 10, 449-469.

Davidson, E., Lefebvre, P.A., Brando, P.M., Ray, D.M., Trumbore, S.E., Solorzano, L.A., Ferrera, J.N., da C. Bustamante, M.M., Nepstad, D.C., 2011. Carbon Inputs and Water Uptake in Deep Soils of an Eastern Amazon Forest. Forest Science 57, 51-58.

Dawson, T.E., 1995. Determining water use by trees and forests from isotopic, energy balance and transpiration analyses: the roles of tree size and hydraulic lift. Tree Physiology 16, 263-272. 
640

641

642

643

644

645

646

647

648

649

650

651

652

653

654

655

656

657

658

659

660

Dawson, T.E., 1996. Determining water use by trees and forests from isotopic, energy balance and transpiration analyses: the roles of tree size and hydraulic lift. Tree Physiology 16, 263-272.

Diez, J.M., Ibáñez, I., Miller-Rushing, A.J., Mazer, S.J., Crimmins, T.M., Crimmins, M.A., Bertelsen, C.D., Inouye, D.W., 2012. Forecasting phenology: from species variability to community patterns. Ecology letters 15, 545-553.

Dybzinski, R., Farrior, C., Wolf, A., Reich, P.B., Pacala, S.W., 2011. Evolutionarily stable strategy carbon allocation to foliage, wood, and fine roots in trees competing for light and nitrogen: an analytically tractable, individual-based model and quantitative comparisons to data. The American naturalist 177, 153-166.

Dymond, C.C., Scheller, R.M., Beukema, S., 2012. A New Model For Simulating Climate Change and Carbon Dynamics in Forested Landscapes. Journal of Ecosystems and Management 13, 1-2.

Eltrop, L., Marschner, H., 1996. Growth and mineral nutrition of non-mycorrhizal and mycorrhizal Norway spruce (Picea abies) seedlings grown in semi-hydroponic sand culture. New Phytologist 133, 469-478.

Farquhar, G.D., Caemmerer, S.V., Berry, J.A., 1980. A biochemical model of photosynthetic $\mathrm{CO}_{2}$ assimiliation in leaves of C-3 species. Planta 149, 78-90.

Feddes, R.A., Hoff, H., Bruen, M., Dawson, T.E., 2001. Modeling root water uptake in hydrological and climate models. Bulletin of the American Meteorological Society 82, 2797-2810. 
661 Fisher, J.B., Sitch, S., Malhi, Y., Fisher, R.A., Huntingford, C., Tan, S.Y., 2010. Carbon cost of

662

663

664

665

666

667

668

669

670

671

672

673

674

675

676

677

678

679

680

681

682

683

plant nitrogen acquisition: A mechanistic, globally applicable model of plant nitrogen uptake, retranslocation, and fixation. Global Biogeochem Cycles 24.

Fisk, M.C., Yanai, R.D., Fierer, N., 2010. A molecular approach to quantify root community composition in a northern hardwood forest — testing effects of root species, relative abundance, and diameter. Can J For Res 40, 836-841.

Fridley, J.D., 2012. Extended leaf phenology and the autumn niche in deciduous forest invasions. Nature 485, 359-362.

Garrigues, E., Doussan, C., Pierret, A., 2006. Water uptake by plant roots: I - Formation and propagation of a water extraction front in mature root systems as evidenced by 2-D light 25 transmission imaging. Plant and Soil 283, 83-98.

Gaudinski, J.B., Torn, M.S., Riley, W.J., Dawson, T.E., Joslin, J.D., Majdi, H., 2010. Measuring and modeling the spectrum of fine-root turnover times in three forests using isotopes, minirhizotrons, and the Radix model. Global Biogeochem Cycles 24.

Gaudinski, J.B., Torn, M.S., Riley, W.J., Swanston, C., Trumbore, S.E., Joslin, J.D., Majdi, H., Dawson, T.E., Hanson, P.J., 2009. Use of stored carbon reserves in growth of temperate tree roots and leaf buds: analyses using radiocarbon measurements and modeling. Global Change Biol 15, 992-1014.

Gentine, P., D’odorico, P., Lintner, B., Sivandran, G., Salvucci, G., 2012. Interdependence of climate, soil, and vegetation as constrained by the Budyko curve. Geophysical Research Letters 39, L19404.

Gessler, A., Schneider, S., Von Sengbusch, D., Weber, P., Hanemann, U., Huber, C., Rothe, A., Kreutzer, K., Rennenberg, H., 1998. Field and laboratory experiments on net uptake of 
nitrate and ammonium by the roots of spruce (Picea abies) and beech (Fagus sylvatica) trees. New Phytologist 138, 275-285.

Gill, R.A., Jackson, R.B., 2000. Global patterns of root turnover for terrestrial ecosystems. New Phytologist 147, 13-31.

Göransson, H., Wallander, H., Ingerslev, M., Rosengren, U., 2006. Estimating the relative nutrient uptake from different soil depths in Quercus robur, Fagus sylvatica and Picea abies. Plant and Soil 286, 87-97.

Gordon, W.S., Jackson, R.B., 2003. Global Distribution of Root Nutrient Concentrations in Terrestrial Ecosystems. Data set. Available on-line [http://www.daac.ornl.gov] from Oak Ridge National Laboratory Distributed Active archive Center, Oak Ridge, Tennessee, U.S.A. .

Guo, D., Li, H., Mitchell, R.J., Han, W., Hendricks, J.J., Fahey, T.J., Hendrick, R.L., 2008a. Fine root heterogeneity by branch order: exploring the discrepancy in root turnover estimates between minirhizotron and carbon isotopic methods. New Phytol 177, 443-456.

Guo, D., Mitchell, R., Hendricks, J., 2004. Fine root branch orders respond differentially to carbon source-sink manipulations in a longleaf pine forest. Oecologia 140, 450-457.

Guo, D., Xia, M., Wei, X., Chang, W., Liu, Y., Wang, Z., 2008b. Anatomical traits associated with absorption and mycorrhizal colonization are linked to root branch order in twentythree Chinese temperate tree species. New Phytol 180, 673-683.

Guswa, A.J., 2008. The influence of climate on root depth: A carbon cost-benefit analysis. Water Resources Research 44.

Harmon, M., 2011. Forest Sector Carbon Calculator Manual-Landcarbon Version 3.0. landcarb.forestry.oregonstate.edu, 1-110. 
Hendrick, R.L., Pregitzer, K.S., 1992. The Demography of Fine Roots in a Northern Hardwood Forest. Ecology 73, 1094-1104.

Hendricks, J.J., Hendrick, R.L., Wilson, C.A., Mitchell, R.J., Pecot, S.D., Guo, D., 2006. Assessing the patterns and controls of fine root dynamics: an empirical test and methodological review. Journal of Ecology 94, 40-57.

Hendricks, J.J., Nadelhoffer, K.J., Aber, J.D., 1993. Assessing the role of fine roots in carbon and nutrient cycling. TREE 8, 174.

Hildebrandt, A., 2005. Ecohydrology of a Seasonal Cloud Forest in Dhofar, Civil and Environmental Engineering. Massachusetts Institute of Technology, Cambridge.

Hopmans, J.W., Bristow, K.L., 2002. Current capabilities and future needs of root water and nutrient uptake modeling. Advances in Agronomy, Vol 77 77, 103-183.

Hwang, T., Band, L., Hales, T.C., 2009. Ecosystem processes at the watershed scale: Extending optimality theory from plot to catchment. Water Resources Research 45.

Ingestad, T., Agren, G.I., 1991. The influence of plant nutrition on biomass allocation. Ecol Appl $1,168-174$.

Iversen, C.M., 2010. Digging deeper: fine-root responses to rising atmospheric CO2 concentration in forested ecosystems. New Phytol 186, 346-357.

Iversen, C.M., Ledford, J., Norby, R.J., 2008. CO2 enrichment increases carbon and nitrogen input from fine roots in a deciduous forest. New Phytologist 179, 837-847.

Jackson, R.B., Mooney, H.A., Schulze, E.D., 1997. A global budget for fine root biomass, surface area, and nutrient contents. Proceedings of the National Academy of Sciences 94, $7362-7366$ 
Jackson, R.B., Moore, L.A., Hoffmann, W.A., Pockman, W.T., Linder, C.R., 1999. Ecosystem rooting depth determined with caves and DNA. Proceedings of the National Academy of Sciences 96, 11387-11392.

Jackson, R.B., Schenk, H.J., Jobbagy, E.G., Canadell, J.G., Colello, G.D., Dickenson, R.E., Field, C.B., Friedlingstein, P., Heimann, M., Hibbard, K., Kicklighter, D.W., Kleidon, A., Neilson, R.P., Parton, W.J., Sala, O.E., Sykes, M.T., 2000. Belowground consequences of vegetation change and their treatment in models. Ecol Appl 10, 470-483.

Jain, A.K., Meiyappan, P., Song, Y., House, J.I., 2013. CO2 emissions from land-use change affected more by nitrogen cycle, than by the choice of land-cover data. Global Change Biology, n/a-n/a.

Jarvis, N.J., 2011. Simple physics-based models of compensatory plant water uptake: concepts and eco-hydrological consequences. Hydrology and Earth System Sciences 15, 34313446.

Javaux, M., Couvreur, V., Vander Borght, J., Vereecken, H., 2013. Root Water Uptake: From Three-Dimensional Biophysical Processes to Macroscopic Modeling Approaches. Vadose Zone Journal 12.

Johnson, I.R., Thornley, J.H.M., 1987. A Model of shoot: root partitioning with optimal growth. Annals of Botany 60, 133-142.

Kashian, D.M., Romme, W.H., Tinker, D., Turner, M.G., Ryan, M.G., 2013. Post-fire changes in forest carbon storage over a 300-year chronosequence of Pinus contorta-dominated forests. Ecol Monog 83, 49-66. 
Keane, R.E., Loehman, R.A., Holsinger, L.M., 2011. The FireBGCv2 Landscape Fire Succession Model: A Research Simulation Platform for Exploring Fire and Vegetation Dynamics. US Department of Agriculture, Forest Service, Rocky Mountain Research Station.

Kleidon, A., Heimann, M., 1998. A method of determining rooting depth from a terrestrial biosphere model and its impacts on the global water and carbon cycle. Global Change Biology 4, 275-286.

Kulmatiski, A., Beard, K., 2012. Root niche partitioning among grasses, saplings, and trees measured using a tracer technique. Oecologia, 1-13.

Kulmatiski, A., Beard, K.H., Verweij, R.J.T., February, E.C., 2010. A depth-controlled tracer technique measures vertical, horizontal and temporal patterns of water use by trees and grasses in a subtropical savanna. New Phytologist 188, 199-209.

Lai, C., Katul, G., 2000. The dynamic role of root-water uptake in coupling potential to actual transpiration. Advances in Water Resources 23, 427-439.

LeBauer, D.S., Wang, D., Richter, K.T., Davidson, C.C., Dietze, M.C., 2013. Facilitating feedbacks between field measurements and ecosystem models. Ecol Monog 83, 133-154.

Lee, E.H., Tingey, D.T., Beedlow, P.A., Johnson, M.G., Burdick, C.A., 2007. Relating fine root biomass to soil and climate conditions in the Pacific Northwest. Forest Ecology and Management 242, 195-208.

Levis, S., Bonan, G.B., Vertenstein, M., Oleson, K.W., 2004. The Community Land Model's Dynamic Global Vegetation Model (CLM-DGVM): Technical Description and User's Guide. NCAR Tech. Note TN-459, 1-50. 
Li, L.H., Wang, Y.P., Yu, Q., Pak, B., Eamus, D., Yan, J.H., van Gorsel, E., Baker, I.T., 2012. Improving the responses of the Australian community land surface model (CABLE) to seasonal drought. Journal of Geophysical Research-Biogeosciences 117.

Lucash, M.S., Eissenstat, D.M., Joslin, J.D., McFarlane, K.J., Yanai, R.D., 2007. Estimating nutrient uptake by mature tree roots under field conditions: challenges and opportunities. Trees-Structure and Function 21, 593-603.

Lucash, M.S., Yanai, R.D., Joslin, J.D., 2008. Nutrient uptake by intact and disturbed roots of loblolly pine seedlings. Environ. Exp. Bot. 64, 15-20.

Luo, Y., Su, B., Currie, W.S., Dukes, J.S., Finzi, A., Hartwig, U., Hungate, B.A., McMurtrie, R.E., Oren, R., Parton, W.J., Pataki, D.E., Shaw, M.R., Zak, D., Field, C.B., 2004. Progressive nitrogen limitation of ecosystem responses to rising atmospheric carbon dioxide. BioScience 54, 731-739.

Malhi, Y., Doughty, C., Galbraith, D., 2011. The allocation of ecosystem net primary productivity in tropical forests. Philosophical Transactions of the Royal Society B: Biological Sciences 366, 3225-3245.

Manabe, S., 1696. Climate and Ocean Circulation .I. Atmospheric Circulation and Hydrology of Earths Surface. Mon Weather Rev 97, 739-774.

Matamala, R., Gonzalez-Meler, M.A., Jastrow, J.D., Norby, R.J., Schlesinger, W.H., 2003. Impacts of fine root turnover on forest NPP and soil C sequestration potential. Science $302,1385-1387$.

McCormack, M.L., Adams, T.S., Smithwick, E.A.H., Eissensat, D.M., in press. Variability in root production, phenology, and turnover rate among 12 temperate tree species. Ecology. 
McCormack, M.L., Eissensat, D.M., Prasad, A., Smithwick, E.A.H., 2013. Regional scale patterns of fine root lifespan and turnover under current and future climate. Global Change Biol 19, 1697-1708.

McCulley, R.L., Jobbagy, E.G., Pockman, W.T., Jackson, R.B., 2004. Nutrient uptake as a contributing explanation for deep rooting in arid and semi-arid ecosystems. Oecologia $141,620-628$.

McMurtrie, R.E., Iversen, C.M., Dewar, R.C., Medlyn, B.E., Näsholm, T., Pepper, D.A., Norby, R.J., 2012. Plant root distributions and nitrogen uptake predicted by a hypothesis of optimal root foraging. Ecology and Evolution 2, 1235-1250.

Medvigy, D., Wofsy, S.C., Munger, J.W., Hollinger, D.Y., Moorcroft, P.R., 2009. Mechanistic scaling of ecosystem function and dynamics in space and time: Ecosystem Demography model version 2. J. Geophys. Res. 114.

Metherell, A.K., Harding, L.A., Cole, C.V., William, J., 2010. CENTURY Soil Organic Matter Model Environment Technical Documentation. Colorado State University.

Milchunas, D.G., 2009. Estimating Root Production: Comparison of 11 Methods in Shortgrass Steppe and Review of Biases. Ecosystems 12, 1381-1402.

Millar, C.I., Stephenson, N.L., Stephens, S.L., 2007. Climate change and forests of the future: Managing in the face of uncertainty. Ecol Appl 17, 2145-2151.

Mommer, L., Wagemaker, C.A.M., De Kroon, H., Ouborg, N.J., 2008. Unravelling belowground plant distributions: a real-time polymerase chain reaction method for quantifying species proportions in mixed root samples. Molecular Ecology Resources 8, 947-953.

Mote, P.W., Parson, E.A., Hamlet, A.F., Ideker, K.N., Keeton, W.S., Lettenmaier, D.P., Mantua, N.J., Miles, E.L., Peterson, D.W., Peterson, D.L., Slaughter, R., Snover., A.K., 2003. 
Preparing for climatic change: The water, salmon, and forests of the Pacific Northwest. Climatic Change 61, 45-88.

818 819 820 821

822 823 824 825 826

827 828 829 830 831 832 833 834 835 836

Nadelhoffer, K.J., 2000. The potential effects of nitrogen deposition on fine-root production in forest ecosystems. New Phytol 147, 131-139.

Nadezhdina, N., Ferreira, M., Silva, R., Pacheco, C., 2008. Seasonal variation of water uptake of a Quercus suber tree in Central Portugal. Plant and Soil 305, 105-119.

Neumann, R.B., Cardon, Z.G., 2012. The magnitude of hydraulic redistribution by plant roots: a review and synthesis of empirical and modeling studies. New Phytologist 194, 337-352.

Norby, R.J., Warren, J.M., Iversen, C.M., Medlyn, B.E., McMurtrie, R.E., 2010. CO2 enhancement of forest productivity constrained by limited nitrogen availability. Proceedings of the National Academy of Sciences 107, 19368-19373.

Oleson, K.W., Lawrence, D.M., Bonan, G.B., Flanner, M.G., Kluzek, E., Lawrence, P.J., Levis, S., Swenson, S.C., Thornton, P.E., Dai, A., 2010. Technical Description of version 4.0 of the Community Land Model (CLM) Rep., 257 pp. National Center for Atmospheric Research, Boulder, CO.

Ollinger, S.V., Aber, J.D., Reich, P.B., Freuder, R.J., 2002. Interactive effects of nitrogen deposition, tropospheric ozone, elevated $\mathrm{CO} 2$ and land use history on the carbon dynamics of northern hardwood forests. Global Change Biology 8, 545-562.

Öpik, M., Zobel, M., Cantero, J., Davison, J., Facelli, J., Hiiesalu, I., Jairus, T., Kalwij, J., Koorem, K., Leal, M., Liira, J., Metsis, M., Neshataeva, V., Paal, J., Phosri, C., Põlme, S., Reier, Ü., Saks, Ü., Schimann, H., Thiéry, O., Vasar, M., Moora, M., 2013. Global sampling of plant roots expands the described molecular diversity of arbuscular mycorrhizal fungi. Mycorrhiza, 1-20. 
Orwin, K.H., Kirschbaum, M.U.F., St John, M.G., Dickie, I.A., 2011. Organic nutrient uptake by mycorrhizal fungi enhances ecosystem carbon storage: a model-based assessment. Ecology Letters 14, 493-502.

Ostonen, I., Lõhmus, K., Pajuste, K., 2005. Fine root biomass, production and its proportion of NPP in a fertile middle-aged Norway spruce forest: Comparison of soil core and ingrowth core methods. Forest Ecology and Management 212, 264-277.

Park, B., Yanai, R., Fahey, T., Bailey, S., Siccama, T., Shanley, J., Cleavitt, N., 2008. Fine Root Dynamics and Forest Production Across a Calcium Gradient in Northern Hardwood and Conifer Ecosystems. Ecosystems 11, 325-341.

Parmesan, C., Yohe, G., 2003. A globally coherent fingerprint of climate change impacts across natural systems. Nature 421, 37-42.

Parton, W.J., Hanson, P.J., Swanston, C., Torn, M., Trumbore, S.E., Riley, W., Kelly, R., 2010. ForCent model development and testing using the Enriched Background Isotope Study experiment. Journal of Geophysical Research 115, G04001.

Pitman, A.J., 2003. The evolution of, and revolution in, land surface schemes designed for climate models. International Journal of Climatology 23, 479-510.

Poorter, H., Nagel, O., 2000. The role of biomass allocation in the growth response of plants to different levels of light, $\mathrm{CO}_{2}$, nutrients and water: a quantitative review. Australian Journal of Plant Physiology 27, 595-607.

Pregitzer, K.S., 2002. Fine roots of trees - a new perspective. New Phytologist 154, 267-270.

Pregitzer, K.S., Laskowski, M.J., Burton, A.J., Lessard, V.C., Zak, D.R., 1998. Variation in sugar maple root respiration with root diameter and soil depth. Tree Phys 18, 665-670. 
Proe, M.F., Midwood, A.J., Craig, J., 2000. Use of stable isotopes to quantify nitrogen, potassium and magnesium dynamics in young Scots pine (Pinus sylvestris). New Phytologist 146, 461-469.

Richardson, A.D., Anderson, R.S., Arain, M.A., Barr, A.G., Bohrer, G., Chen, G.S., Chen, J.M., Ciais, P., Davis, K.J., Desai, A.R., Dietze, M.C., Dragoni, D., Garrity, S.R., Gough, C.M., Grant, R., Hollinger, D.Y., Margolis, H.A., McCaughey, H., Migliavacca, M., Monson, R.K., Munger, J.W., Poulter, B., Raczka, B.M., Ricciuto, D.M., Sahoo, A.K., Schaefer, K., Tian, H.Q., Vargas, R., Verbeeck, H., Xiao, J.F., Xue, Y.K., 2012. Terrestrial biosphere models need better representation of vegetation phenology: results from the North American Carbon Program Site Synthesis. Global Change Biology 18, $566-584$.

Robinson, D., 2004. Scaling the depths: Below-ground allocation in plants, forests and biomes. Functional Ecology 18, 290-295.

Santantonio, D., Hermann, R.K., Overton, W.S., 1977. Root biomass studies in forest ecosystems. Pedobiologia 17, 1-31.

Schaefer, K., Collatz, G.J., Tans, P., Denning, A.S., Baker, I., Berry, J., Prihodko, L., Suits, N., Philpott, A., 2008. Combined Simple Biosphere/Carnegie-Ames-Stanford Approach terrestrial carbon cycle model. J Geophys Res-Biogeo 113.

Scheller, R.M., Hua, D., Bolstad, P.V., Birdsey, R.A., Mladenoff, D.J., 2011. The effects of forest harvest intensity in combination with wind disturbance on carbon dynamics in Lake States Mesic Forests. Ecological Modelling 222, 144-153. 
Scheller, R.M., Kretchun, A.M., Tuyl, S.V., Clark, K.L., Lucash, M.S., Hom, J., In press. Divergent carbon dynamics under climate change in the New Jersey Pine Barrens, USA. Ecosphere.

Schenk, H.J., 2008. The Shallowest Possible Water Extraction Profile: A Null Model for Global Root Distributions. Vadose Zone Journal 7, 1119-1124.

Schenk, H.J., Jackson, R.B., 2002. The global biogeography of roots. Ecol Monog 72, 311-328.

Schnepf, A., Roose, T., Schweiger, P., 2008a. Growth model for arbuscular mycorrhizal fungi. Journal of the Royal Society Interface 5, 773-784.

Schnepf, A., Roose, T., Schweiger, P., 2008b. Impact of growth and uptake patterns of arbuscular mycorrhizal fungi on plant phosphorus uptake - a modelling study. Plant and Soil 312, 85-99.

Schymanski, S.J., Sivapalan, M., Roderick, M.L., Beringer, J., Hutley, L.B., 2008. An optimality-based model of the coupled soil moisture and root dynamics. Hydrology and Earth System Sciences Discussions 5, 51-94.

Schymanski, S.J., Sivapalan, M., Roderick, M.L., Hutley, L.B., Beringer, J., 2009. An optimality-based model of the dynamic feedbacks between natural vegetation and the water balance. Water Resources Research 45.

Sharp, R.E., Davies, W.J., 1985. Root growth and water uptake by maize plants in drying soil. Journal of Experimental Botany 36, 1441-1456.

Shevliakova, E., Pacala, S.W., Malyshev, S., Hurtt, G.C., Milly, P.C.D., Caspersen, J.P., Sentman, L.T., Fisk, J.P., Wirth, C., Crevoisier, C., 2009. Carbon cycling under 300 years of land use change: Importance of the secondary vegetation sink. Global Biogeochemical Cycles 23. 
Simunek, J., Hopmans, J.W., 2009. Modeling compensated root water and nutrient uptake. Ecol Model 220, 505-521.

Sivandran, G., Bras, R.L., 2013. Dynamic root distributions in eco-hydrological modeling: A case study at Walnut gulch experimental watershed. Water Resources Research In press.

Sivandran, G., L.Bras, R., 2012. Identifying the optimal spatially and temporally invariant root distribution for a semiarid environment. Water Resources Research 48.

Smit, A.L., Bengough, A.G., Engels, C., van Noordwijk, M., Pellerin, S., van de Geijn, S.C., 2000. Root methods: a handbook. Springer.

Smith, S., Read, D., 2008. Mycorrhizal Symbiosis. Elsevier, NY, NY.

Smithwick, E.A.H., Eissensat, D.M., Lovett, G.M., Bowden, R.D., Rustad, L.E., Driscoll, C.T., 2013. Root stress and nitrogen deposition: Consequences and research priorities. New Phytol 197, 1697-1708.

Soethe, N., Lehmann, J., Engels, C., 2006. The vertical pattern of root and nutrient uptake at different altitudes of a south Ecuadorian montane forest. Plant and Soil 286, 287-299.

Steinaker, D.F., Wilson, S.D., Peltzer, D.A., 2010. Asynchronicity in root and shoot phenology in grasses and woody plants. Global Change Biol 16, 2241-2251.

Stover, D.B., Day, F.P., Butnor, J.R., Drake, B.G., 2007. Effect of elevated $\mathrm{CO}_{2}$ on coarse-root biomass in Florida scrub detected by ground-penetrating radar. Ecology 88, 1328-1334.

Taylor, B., Beidler, K., Strand, A., Pritchard, S., 2014. Improved scaling of minirhizotron data using an empirically-derived depth of field and correcting for the underestimation of root diameters. Plant Soil 374, 941-948. 
Thornton, P.E., Lamarque, J.F., Rosenbloom, N.A., Mahowald, N.M., 2007. Influence of carbonnitrogen cycle coupling on land model response to $\mathrm{CO}(2)$ fertilization and climate variability. Global Biogeochemical Cycles 21.

Tian, H., Melillo, J.M., Lu, C., Kicklighter, D.W., Liu, M., Ren, W., Xu, X., Chen, G., Zhang, C., Pan, S., 2011. China's terrestrial carbon balance: Contributions from multiple global change factors.

Tierney, G.L., Fahey, T.J., 2002. Fine root turnover in a northern hardwood forest: a direct comparison of the radiocarbon and minirhizotron methods. Canadian Journal of Forest Research-Revue Canadienne De Recherche Forestiere 32, 1692-1697.

Tjoelker, M.G., Craine, J.M., Wedin, D., Reich, P.B., Tilman, D., 2005. Linking leaf and root trait syndromes among 39 grassland and savannah species. New Phytologist 167, 493508.

Treseder, K.K., Balser, T.C., Bradford, M.A., Brodie, E.L., Dubinsky, E.A., Eviner, V.T., Hofmockel, K.S., Lennon, J.T., Levine, U.Y., MacGregor, B.J., Pett-Ridge, J., Waldrop, M.P., 2012. Integrating microbial ecology into ecosystem models: challenges and priorities. Biogeochem 109, 7-18.

Treseder, K.K., Turner, K.M., Mack, M.C., 2007. Mycorrhizal responses to nitrogen fertilization in boreal ecosystems: potential consequences for soil carbon storage. DOI:10.1111/j.1365-2486.2006.01279.x. Global Change Biol 13, 78-88.

Vadeboncoeur, M.A., Hamburg, S.P., Yanai, R.D., 2007. Validation and refinement of allometric equations for roots of northern hardwoods. Canadian Journal of Forest Research 37, 1777-1783. 
Vargas, R., 2009. On the fate of old stored carbon after large-infrequent disturbances in plants. Plant signaling \& behavior 4, 617-619.

Vogt, K.A., Vogt, D.J., Bloomfield, J., 1998. Analysis of some direct and indirect methods for estimating root biomass and production of forests at an ecosystem level. Plant and Soil 200, 71-89.

Wan, C.G., Yilmaz, I., Sosebee, R.E., 2002. Seasonal soil-water availability influences snakeweed, root dynamics. Journal of Arid Environments 51, 255-264.

Wang, D., LeBauer, D., Dietze, M.C., 2012. Predicting yields of short-rotation hybrid poplar (Populus spp.) for the contiguous US through model-data synthesis. Ecol Appl.

Withington, J.M., Reich, P.B., Oleksyn, J., Eissenstat, D.M., 2006. Comparisons of structure and life span in roots and leaves among temperate trees. Ecological Monographs 76, 381-397.

Wolf, A., Ciais, P., Bellassen, V., Delbart, N., Field, C.B., Berry, J.A., 2011. Forest biomass allometry in global land surface models. Global Biogeochem Cycles 25.

Xia, M., Guo, D., Pregitzer, K.S., 2010. Ephemeral root modules in Fraxinus mandshurica. New Phytol 188, 1065-1074.

Yanai, R.D., Fisk, M.C., Fahey, T.J., Cleavitt, N.L., Park, B.B., 2008. Identifying roots of northern hardwood species: patterns with diameter and depth. Can J For Res 38, 28622869.

Yang, H., Auerswald, K., Bai, Y., Han, X., 2011. Complementarity in water sources among dominant species in typical steppe ecosystems of Inner Mongolia, China. Plant and Soil 340, 303-313. 
969 Yuan, Z.Y., Chen, H.Y.H., 2012. A global analysis of fine root production as affected by soil

970

971

972

973

974

975

976

977

978

979

980

981 nitrogen and phosphorus. Proceedings of the Royal Society B: Biological Sciences 279, 3796-3802.

Zaehle, S., Friend, A.D., 2010. Carbon and nitrogen cycle dynamics in the O-CN land surface model: 1. Model description, site-scale evaluation, and sensitivity to parameter estimates. Global Biogeochem Cycles 24.

Zeng, X.B., 2001. Global vegetation root distribution for land modeling. Journal of Hydrometeorology 2, 525-530.

Zhu, B., Cheng, W., 2011. Rhizosphere priming effect increases the temperature sensitivity of soil organic matter decomposition. Global Change Biology 17, 2172-2183. 
982 Table 1. Issues and approaches (empirical and modeling) for the five key root processes 983 described here. * represents model or analytical study.

984 


\begin{tabular}{|c|c|c|c|}
\hline & & de or Challenge & Relevant empirical or modeling studies \\
\hline & Classif & $\begin{array}{l}\text { Roots currently modeled based } \\
\text { on size class, but empirical } \\
\text { studies show functional } \\
\text { classifications, including fungal } \\
\text { symbioses, are important }\end{array}$ & $\begin{array}{l}\text { Gaudinski et al. 2010; Opik et al. 2010; Xia } \text { et } \\
\text { al. 2010; Clemmensen et al. 2010; Guo et al. } \\
\text { 2008b; Pregitzer 2002; Treseder et al. 2012*; } \\
\text { Parton et al. 2010* }\end{array}$ \\
\hline (2) & Production \& & $\begin{array}{l}\text { Root production classically } \\
\text { modeled based on optimization } \\
\text { to meet aboveground plant } \\
\text { demand, making it difficult to } \\
\text { predict seasonal mismatches in } \\
\text { root vs. aboveground } \\
\text { production }\end{array}$ & $\begin{array}{l}\text { McCormack et al. in prep.;Yuan and Chen } \\
\text { 2012; Brassard et al. } 2011 \\
\text { Burton et al. 2000; Steinaker et al. 2010; } \\
\text { Oleson et al. 2010*; Parton et al. 2010* }\end{array}$ \\
\hline (3) & Turnover \& Lifespan & $\begin{array}{l}\text { Turnover can be defined } \\
\text { differently, leading to } \\
\text { confusion; } \\
\text { root physiology may directly } \\
\text { influence lifespan }\end{array}$ & $\begin{array}{l}\text { Smithwick et al. 2013; McCormack et al. } \\
\text { 2012; Guo et al. 2011; Iverson et al. 2008; } \\
\text { Withington et al. 2006; Gill and Jackson 2000; } \\
\text { Cronan and Grigal } 1995\end{array}$ \\
\hline (4) & Biomass & $\begin{array}{l}\text { Estimating root biomass via } \\
\text { radar, allometry, or soil cores is } \\
\text { difficult; results show variation } \\
\text { with resources, tree size, } \\
\text { climate, \& species }\end{array}$ & $\begin{array}{l}\text { McCormack et al. 2012; Jackson 2009; Iversen } \\
\text { et al. 2008; Park et al. 2008; Pregitzer et al. } \\
\text { 2008; Butnor et al. 2003; Nadelhoffer 2000; } \\
\text { Jackson et al. } 1997\end{array}$ \\
\hline
\end{tabular}


(5) Resource uptake \& Increasing evidence that roots Gentine et al. 2012; Lucash et al. 2007; Caylor Rooting depth influence the soil resource et al. 2006; Soethe et al. 2006; Comas and environment (i.e., priming, Eissenstat 2004; Schenk and Jackson 2002; hydraulic lift), but field Jackson et al. 2000; Proe et al. 2000; measurements remain limited; BassiriRad et al. 1999; Gessler et al. 1998; Models show large sensitivities Sivandran and Bras 2012*, 2013*; Li et al. to rooting depth \& resource 2012*; McMurtrie et al. 2012*; Tian et al. supply; analytical model 2011*; Fisher et al. 2010*; Zaehle and Friend approaches, based on dynamic 2010*; Collins and Bras 2007*; Zeng 2001*; allocation with resource supply Kleidon and Heimann 1998*

by depth and root-level

physiology, are emerging 
987 Table 2: Recommendations for improving the representation of roots in models and examples of how to implement them.

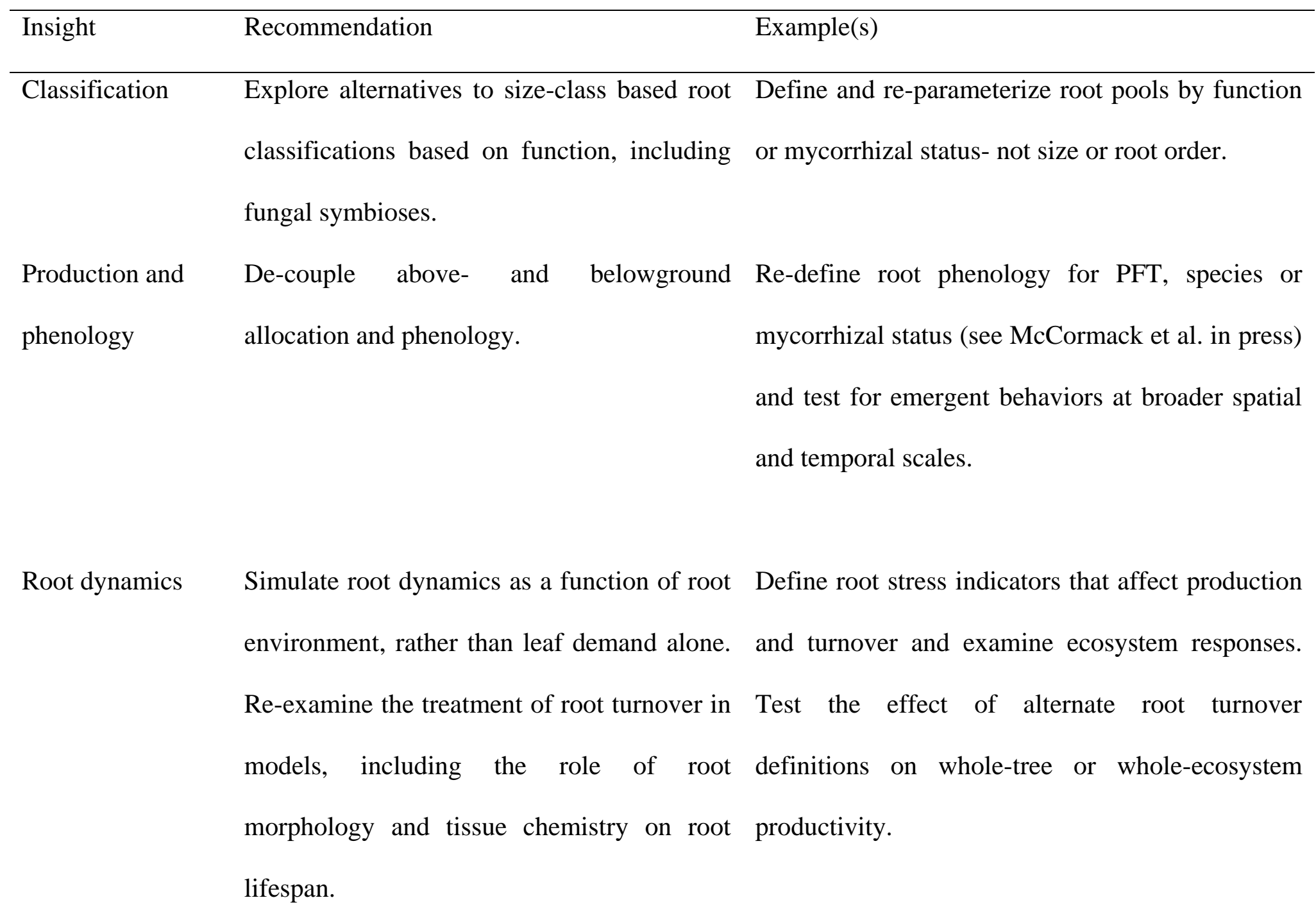


Biomass

Incorporate better estimates of root stocks

across sites and species to parameterize or

validate models.

Resource uptake

and rooting depth

Explore (dynamic) rooting depth patterns on

resource availability and uptake. datasets to test parameter influence on model uncertainty metrics.

Use data-assimilation methods (LeBauer et al., 2013) to take advantage of growing empirical

Develop dynamic approaches to discretize root uptake by matching root mass (or uptake rate) by resource availability in each horizon. 


\section{Figure Legends}

990 Fig. 1. Intact root branch of Acer saccharum (a) followed by depictions of historical (b) and emerging views of root classification ( $c$ and d). The historical view (b) divides roots into coarse

992 (in black) and fine (in white) roots based on rigid diameter classes. Panel (c) shows a root 993 branch classified by branching order following Pregitzer et al. 2002 while panel (d) classifies roots based on function with ephemeral fine roots (white) being responsible for resource uptake 995 and persistent fine roots (gray) provide framework for fine roots and transport water and nutrients to coarse roots (black). Photo in panel (a) taken by Sarah Kulpa care of Ruth Yanai.

997 Panels b-d courtesy of Dali Guo.

Fig, 2. Depiction of current model algorithms of allocation of $\mathrm{C}$ to roots showing three dominant pathways (fixed allocation, proportional allocation, or carbon cascade).

Fig 3. Alternate pathways by which root allocation can alter total ecosystem carbon. In (a) increases in root allocation can either increase or decrease total ecosystem carbon, depending on whether models consider tradeoffs in ANPP among plant pools, respiratory losses, and resource feedbacks. In (b), constant root allocation can impact total ecosystem $\mathrm{C}$ fluxes if root biomass is 1006 independently altered.

1008 Fig. 4. Primary questions that determine model treatment of root function at different soil 1009 depths. Upper left panel describes multiple approaches used to model water uptake in many 1010 terrestrial biosphere models where soil water uptake is modeled with canopy resistance $\left(\mathrm{r}_{\mathrm{c}}\right)$ as a 1011 function of soil water potential $(\psi)$, or water supply $(\mathrm{S})$ is modeled as a function of volumetric 1012 soil water content (W). 
1013 Fig. 5. Traditional and emerging frameworks for incorporation of root processes into ecosystem 1014 models and dynamic vegetation models.

1015 


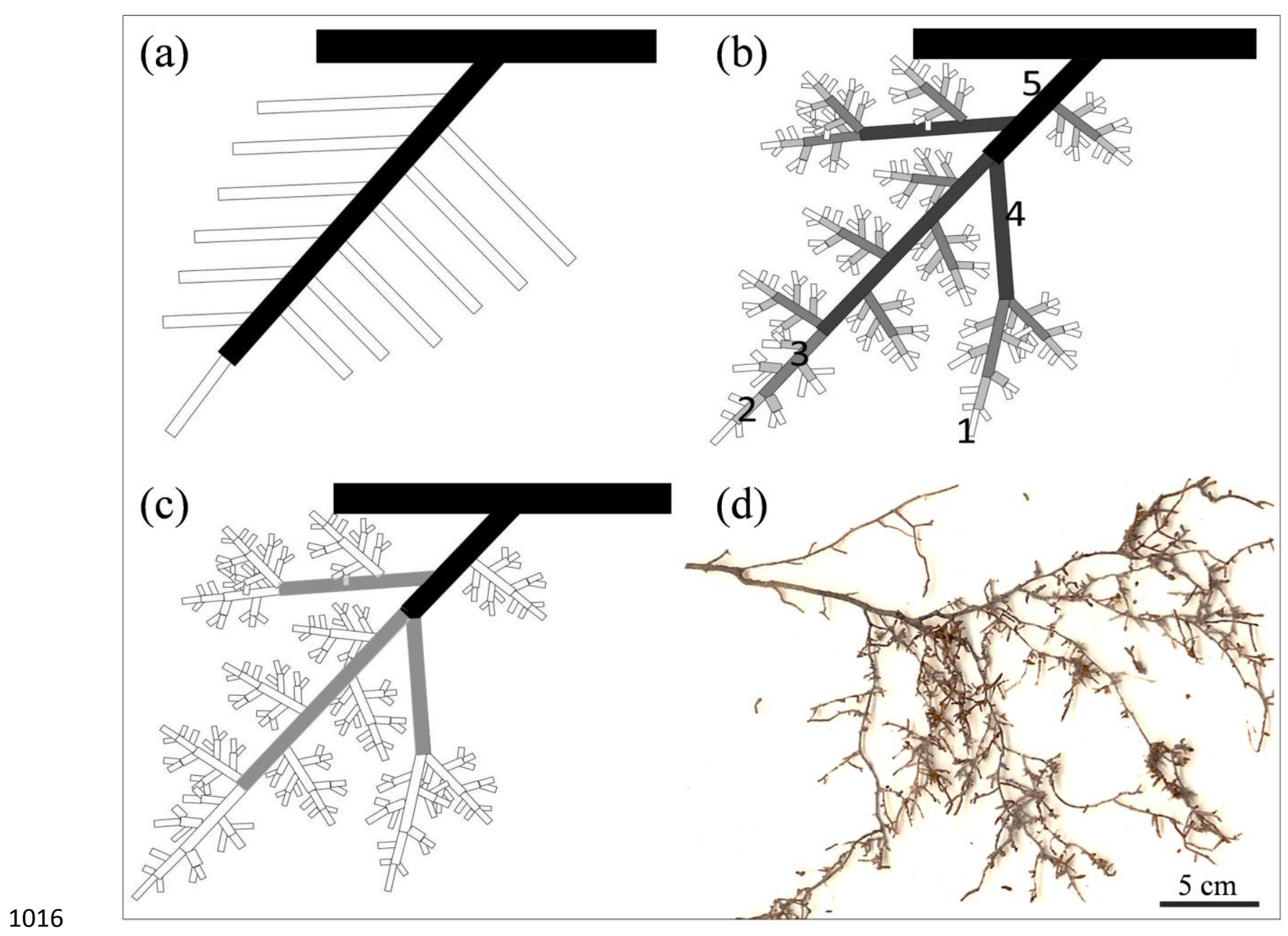

1017 
Fixed Allocation

Allocation to each plant component is a fixed proportion of ANPP

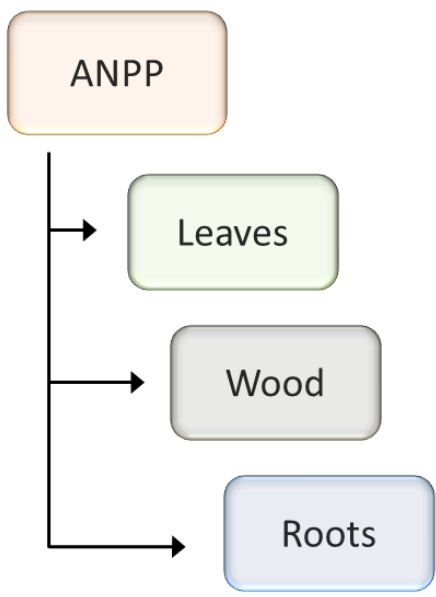

Proportional Allocation Allocation to roots set to maintain a prescribed biomass ratio with other plant components (e.g. leaves)

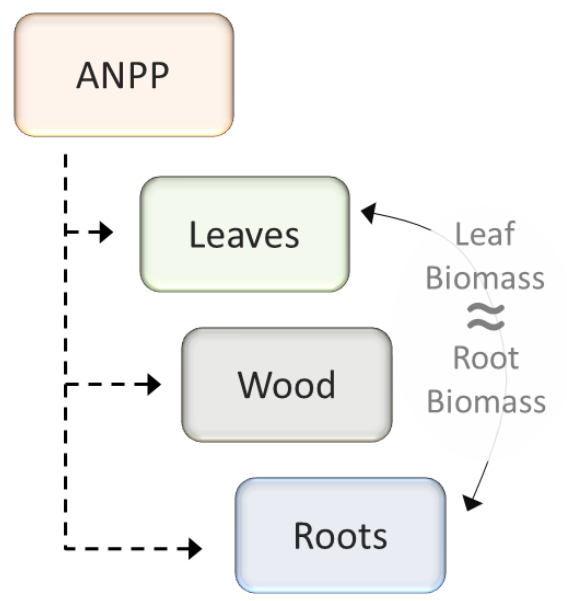

\section{Carbon Cascade} Carbon is allocated first to leaves and then to other plant components until ANPP is used up

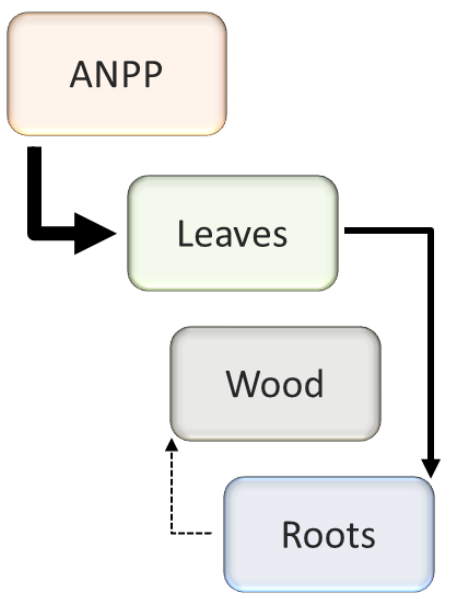


a)

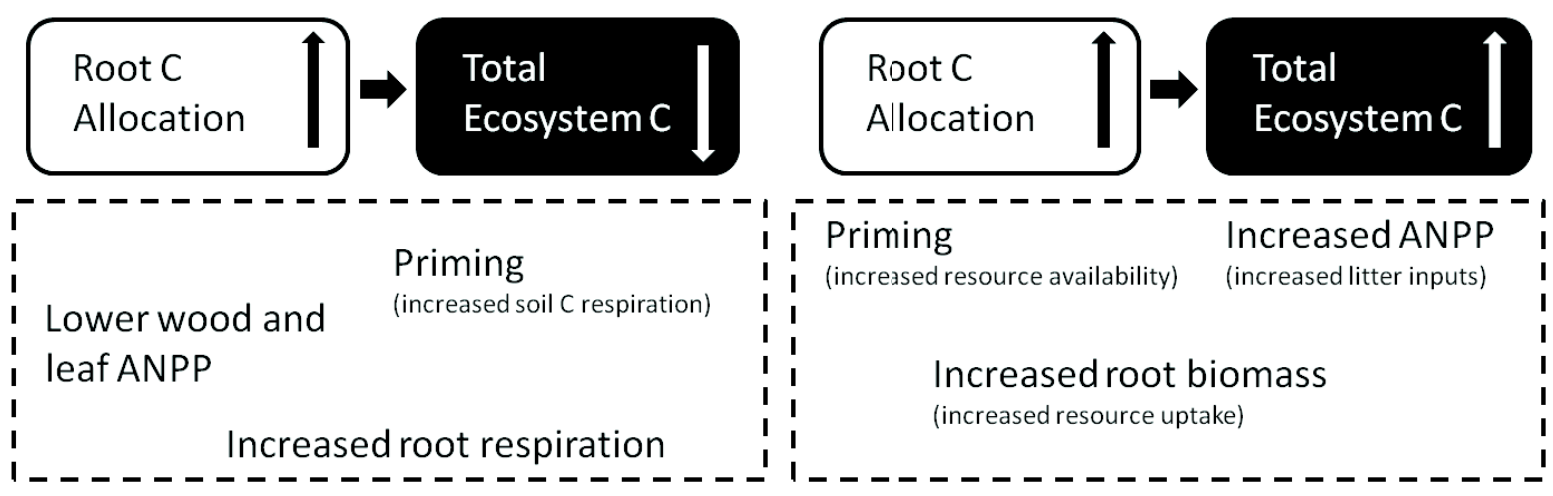

b)

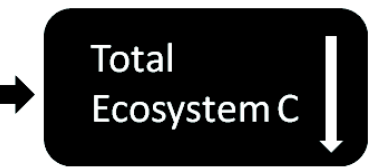

\section{Constant Root \\ Total} C Allocation
Ecosystem C
Decreased root biomass

(decreased resource uptake)

Increased root biomass

(increased root $\mathrm{C}$ respiration)

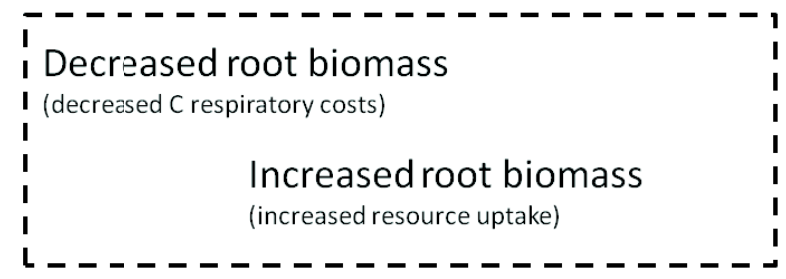


How is soil water uptake calculated?

$$
\begin{gathered}
r_{c}=f(\psi) \\
\text { or } \\
S=f(W)
\end{gathered}
$$

What is the rooting depth distribution?

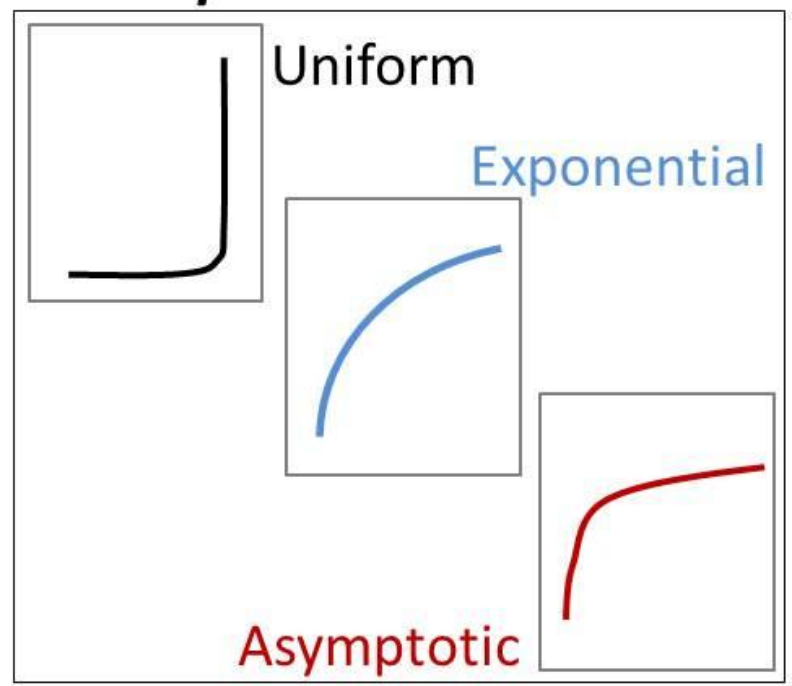

How are root traits prescribed?

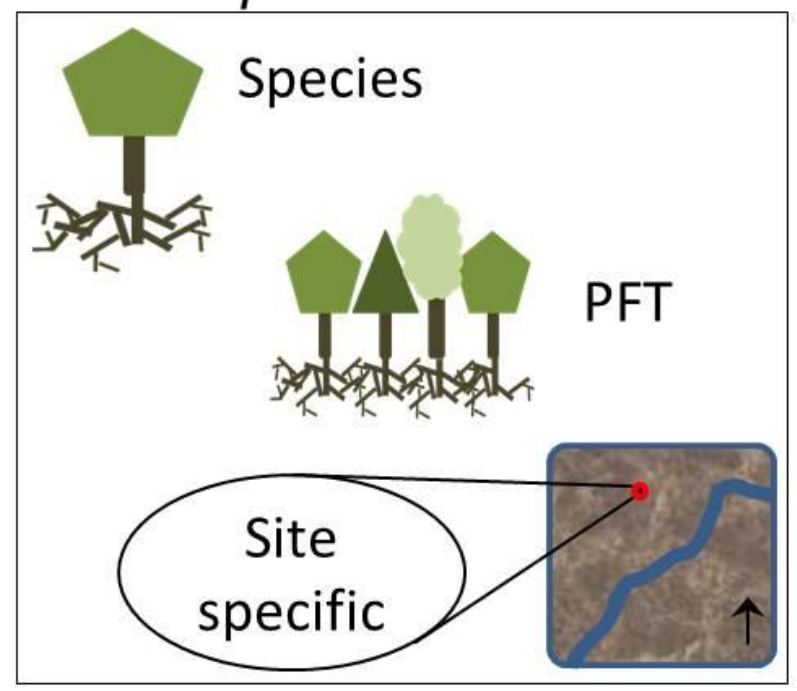

Is the number of soil layers fixed or variable?

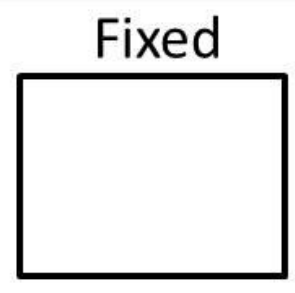

If variable, is it based on plant type, climate, or soil characteristics?

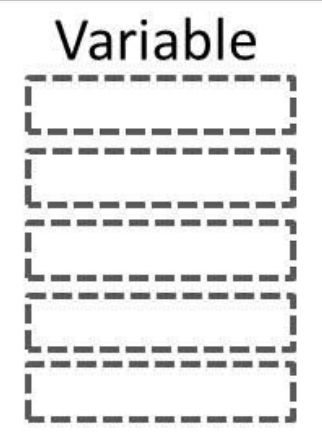

1023 


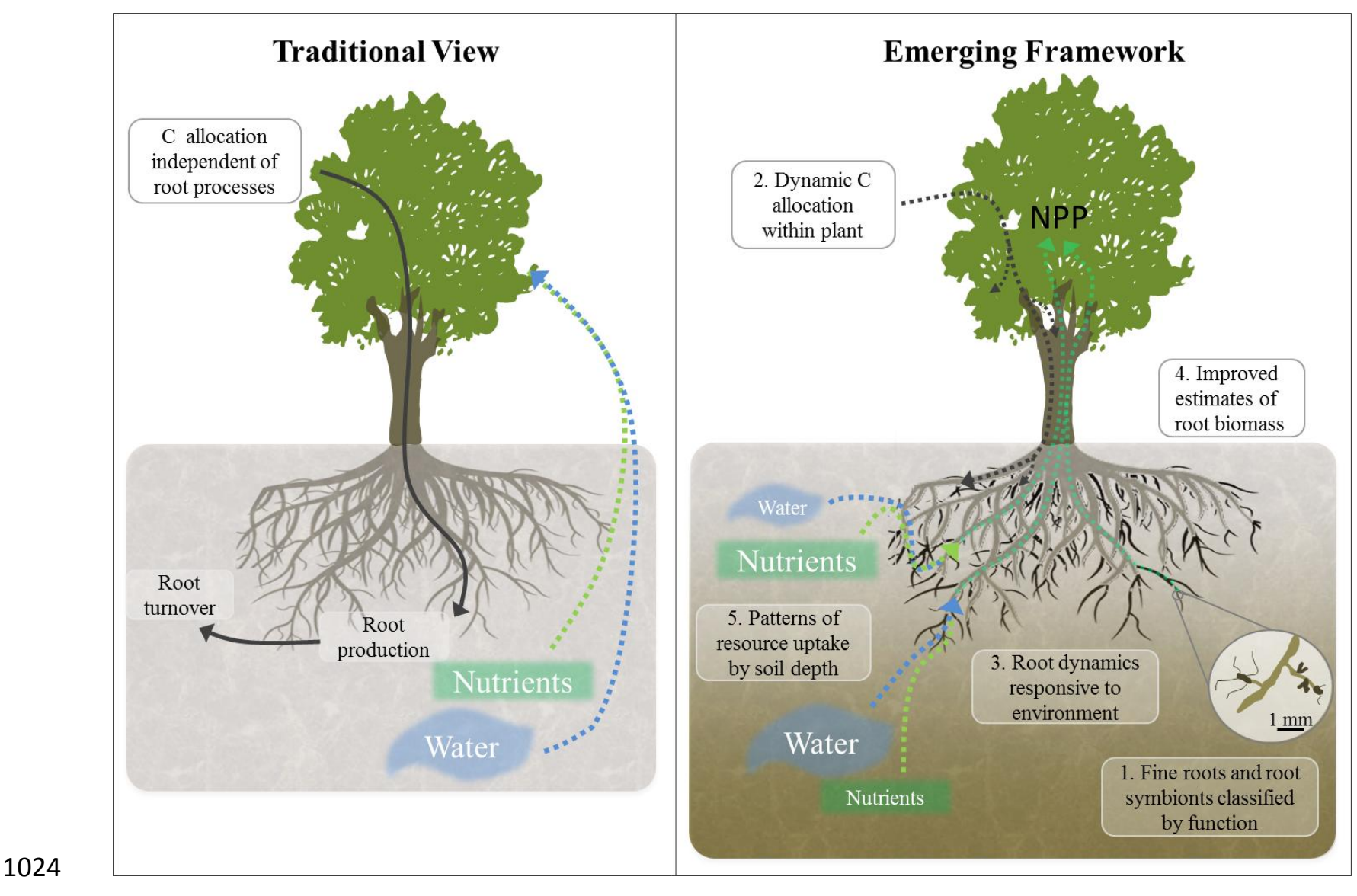

